\author{
Federal Reserve Bank of New York \\ Staff Reports
}

\title{
Counterparty Risk in Material Supply Contracts
}

Nina Boyarchenko

Anna M. Costello

Staff Report No. 694

October 2014

Revised January 2015

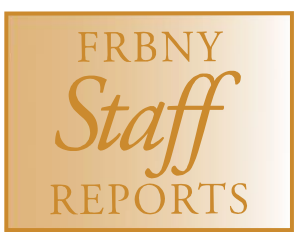

This paper presents preliminary findings and is being distributed to economists and other interested readers solely to stimulate discussion and elicit comments. The views expressed in this paper are those of the authors and do not necessarily reflect the position of the Federal Reserve Bank of New York or the Federal Reserve System. Any errors or omissions are the responsibility of the authors. 


\author{
Counterparty Risk in Material Supply Contracts \\ Nina Boyarchenko and Anna M. Costello \\ Federal Reserve Bank of New York Staff Reports, no. 694 \\ October 2014; revised January 2015 \\ JEL classification: G14, G19, L00, L14
}

\begin{abstract}
This paper explores the sources of counterparty risk in material supply relationships. Using longterm supply contracts collected from SEC filings, we test whether three sources of counterparty risk - financial exposure, product quality risk, and redeployability risk — are priced in the equity returns of linked firms. Our results show that equity holders require compensation for exposure to all three sources of risk. Specifically, offering trade credit to counterparties and investing in relationship-specific assets increase the firm's exposure to counterparty risk. Further, we show that contracts with protective financial covenants and product warranties mitigate the transmission of risk. Overall, we provide evidence on the channels of supply-chain risk, and we show that shareholders recognize the role of contractual features in mitigating counterparty risk.
\end{abstract}

Key words: supply contracts, financial covenants, counterparty risk premia

Boyarchenko: Federal Reserve Bank of New York (e-mail: nina.boyarchenko@ny.frb.org). Costello: MIT Sloan School of Management (e-mail: acostell@mit.edu). The authors thank Bruno Biais, Stijn van Nieuwerburgh, and Or Shachar for helpful comments and discussions. Matthew Yeaton provided excellent research assistance. The views expressed in this paper are those of the authors and do not necessarily reflect the position of the Federal Reserve Bank of New York or the Federal Reserve System. 


\section{Introduction}

Forming long-term partnerships with customers and suppliers often creates a competitive advantage for the firm due to resource sharing, easing financing constraints, and encouraging investment in relationship-specific capital. Consistent with these advantages, Allen and Phillips (2000) find that the formation of product market relationships results in increased stock prices, investment, and operating performance. In addition, Chan, Kensinger, Keown, and Martin (1997) find a positive stock price reaction around the announcement of strategic alliances and find that knowledge and information sharing contribute to the observed positive abnormal returns. Finally, several papers show that supply partners often provide valuable capital to constrained trade partners in the form of trade credit financing (Biais and Gollier, 1997; Petersen and Rajan, 1997).

While significant relationships with customers and suppliers can be beneficial, they also increase firms' exposure to their counterparty's risk. Customers and suppliers often represent significant stakeholders in a firm's operations, particularly if the firms transact on a repeated basis or exchange large volumes of goods. Indeed, research shows that economically linked firms have predictably linked stock returns (Cohen and Frazzini, 2008). Further, the prior literature shows that firms are exposed to their supply partners' negative credit events. When major customers enter bankruptcy, the firm suffers negative stock returns and an increase in CDS spreads (Hertzel, Li, Officer, and Rodgers, 2008; Jorion and Zhang, 2009; Boone and Ivanov, 2012). These observations lead to two important and unanswered questions in the literature. First, which specific characteristics of the trade relationship make a firm more vulnerable to negative spillovers from its supply chain partners? Second, if managers understand these vulnerabilities, can they design a contract to mitigate exposures to negative events?

To answer these questions, we develop a dataset of supply chain links using material contract disclosures from SEC filings. Regulation S-K requires publicly filing firms to dis- 
close contracts with suppliers and customers if the transactions represent purchases or sales that are material to the filer. Therefore, our setting captures economically significant product market relationships that are most likely to influence firm value. Further, we observe the detailed terms of trade, which allows us to identify whether managers anticipate negative supply chain spillovers ex ante and mitigate those spillovers with contractual mechanisms.

To illustrate the effect that contractual terms of trade can have on the transmission of shocks along the supply network, consider the supply contracts between LaJolla Pharmaceutical and BioMarin and LaJolla Pharmaceutical and Abbott Laboratories. On February 12, 2009, LaJolla Pharmaceutical announced that its leading drug candidate, Riquent, failed its Phase 3 clinical trials. The news resulted in a 90\% decline in the value of LaJolla's stock. At the time of the announcement, LaJolla had material supply contracts with both BioMarin and Abbott Laboratories, but BioMarin was significantly more exposed to a negative spillover. Specifically, the supply contract with BioMarin required a \$15 million up-front payment to LaJolla for the marketing rights of Riquent. In contrast, the contract with Abbott Laboratories did not involve up-front payments. As shown in Figure 1, variation in the terms of trade resulted in differential equity market reactions; BioMarin stock declined in value by approximately 35\%, while the stock of Abbott Laboratories was largely unaffected.

The above example illustrates our primary hypothesis: can features of the inter-firm supply agreement impact the relative exposure of firms to supply chain risk? To test this hypothesis, our empirical strategy separates a firm's linked counterparties into two classes based on the degree of exposure the firm has to its counterparty's risk. The first group includes upstream or downstream relationships governed by contracts that restrict the firm's exposure to counterparty risk. The second group includes counterparties that do not face restrictive contractual clauses, and therefore leaves the firm more exposed to spillovers. We then construct long-short equity portfolios for the firm based on the 
Figure 1. LaJolla Pharmaceutical, BioMarin and Abbott Laboratories. Stock prices of LaJolla Pharmaceutical, BioMarin and Abbott Laboratories in February 2009. Prices are normalized $(02 / 05 / 2009=100)$. Source: CRSP.

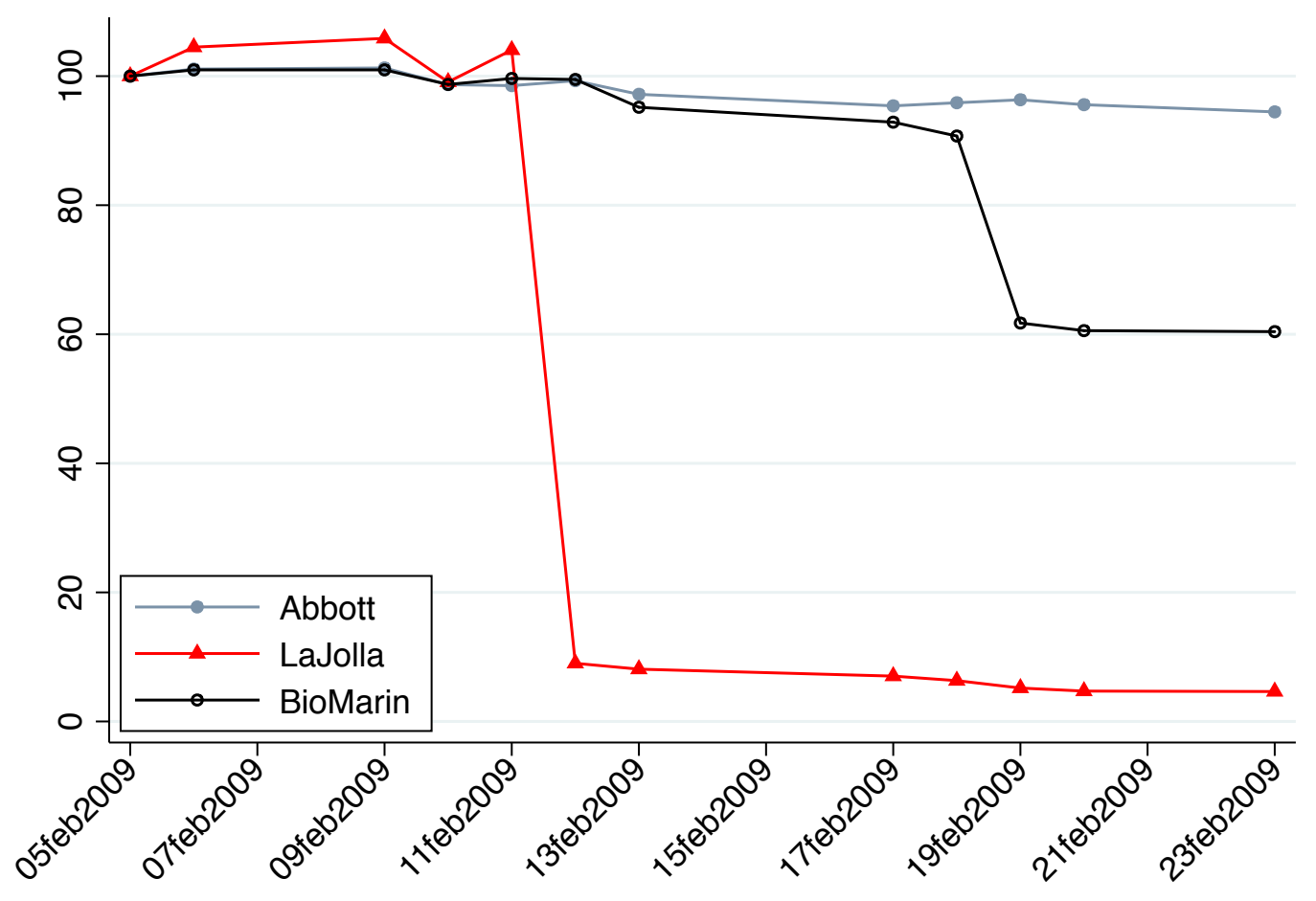

news embedded in the equities of linked firms. The central prediction is that, while the returns of linked supply partners forecast the future returns of the firm, this return predictability varies with respect to contractual protections that mitigate negative supply chain spillovers.

We rely on economic theory to identify three specific channels that can cause counterparty risk to be priced in market returns: credit exposure, product quality risk, and redeployability risk. First, firms can be exposed to the financial risk of their supply chain counterparties if they provide credit to their suppliers or customers when exchanging goods or services. Since trade creditors typically hold subordinate, unsecured claims on the debtor's assets, they face significant downside risk in the event their supplier or customer enters bankruptcy. In addition to the potential loss of trade credit exposures, 
financially distressed counterparties can have a significant impact on the firm's future operations. For example, a distressed customer may reduce its demand for the firm's products and a distressed supplier may reduce the supply of important raw materials. If it is costly for the firm to fill the supply and demand from alternative trade partners, the firm will have a higher exposure to its counterparty's financial distress.

We test whether the financial risk of supply chain counterparties is incorporated in the firm's equity price using three proxies: whether the contract contains financial covenants, whether trade credit is extended, and whether the counterparty has a speculative-grade credit rating. Costello (2013) shows that financial covenants in supply contracts require counterparties to maintain a minimum level of financial performance. Violation of a financial covenant indicates that the party is in default and must cure the default or pay damages. Therefore, a firm that contractually requires their suppliers and customers to maintain financial performance standards should be more protected from financial counterparty risk than a firm that does not. We also test whether trade credit, measured as explicit financing terms in the contract, generates a risk premium. If the firm serves as a creditor to its suppliers by advancing funds before receiving goods or to their customers by allowing them to pay late, it should be more exposed to financial counterparty risk than firms that do not act as creditors to their partners. Finally, if the firm enters trade relationships with speculative-grade counterparties, it is likely to be more exposed to financial risk than if the firm has trade relationships with investment-grade counterparties. We provide evidence that the firm's exposure to credit risk is recognized by market participants; large credit exposures through inter-firm loans result in predictably linked stock returns. We also show that market participants understand the role of financial covenants in mitigating the firm's exposure to linked firms' credit risks. The firm's stock returns are less correlated with their supply partner's returns when the contract has protective covenants than when the contract does not have protective covenants. We do not find that contracting with speculative-grade trade partners impacts risk premiums. 
The second channel of counterparty risk that we investigate is product quality risk. Firms can be exposed to product quality risk because their suppliers are better informed about the quality of inputs and effort used in production. Since it may be costly for firms to distinguish between low- and high-quality products, suppliers will have an incentive to shirk on product quality (Titman, 1984; Maksimovic and Titman, 1991). Even absent incentive conflicts, supply chain glitches due to production problems can impose significant costs on the firm if their suppliers cannot meet expectations (Hendricks and Singhal, 2003).

It is important to note that firms are exposed to product quality risk primarily through their suppliers, rather than through their customers. Therefore, we expect that a shock to a supplier's product quality will have a greater impact on a firm's returns than a shock to a customer's product quality. To test the product quality channel, we investigate whether product warranties mitigate product quality risk. Specifically, if product warranties provide insurance in the event of product failure, firms should have a lower sensitivity to their supplier's risk when their contracts require suppliers to provide warranties. Consistent with this hypothesis, we find that the predictability of customers' return following shocks to their suppliers is reduced when the contract includes product warranties, while the predictability of suppliers' returns in response to shocks to their customers is not affected.

The final channel of counterparty risk is redeployability risk. If the exchange between the firm and its suppliers and customers requires investments in relationship-specific assets, the firm may find it difficult to find a replacement trade partner. Therefore, the counterparty's economic health may affect not only current credit exposures, but it may also impact the firm's ability to source raw materials and to generate revenue in the future.

We use two empirical proxies to capture firms that are more exposed to redeployability risk. First, we determine whether the firm makes a significant investment in capital related to the exchange. This information is taken from the investment requirements 
identified in the contract. If the firm makes a capital investment, it is more exposed to the counterparty's returns since it is costly to switch to an alternative partner. Second, we measure the concentration index of the counterparty's industry. If the firm's suppliers or customers operate in highly concentrated industries, it is more difficult to switch to alternative supply partners than if their partners operate in dispersed, competitive industries. We provide evidence that counterparty risk due to relationship-specific investments commands a risk premium. However, we do not find that contracting with a customer or a supplier in a concentrated industry exposes the firm to additional risk.

Our evidence is consistent with the hypothesis that three types of supply chain risks - financial risk, product quality risk, and redeployability risk - exacerbate the firm's exposure to negative spillovers and that these risks can be mitigated through contractual features. However, we recognize that our inferences could be confounded by omitted variables. First, one might observe higher return predictability among linked firms due to a common economic shock, rather than due to the transmission of financial, product quality, or redeployability risk from the contractual counterparty. Second, it is possible that an omitted variable determines both the propensity of firms to include contractual features and the correlation in stock returns. We address these concerns in three ways. First, we conduct a placebo test for the return predictability of linked firms in the period before they form a contractual relationship. We do not observe linked returns during this placebo period, indicating that the results are not merely a reflection of a correlation in cash flows rather than a contractual exposure. Second, we conduct an event study around the press release announcing the supply partnership and an event study around the disclosure of the full supply contract. The evidence suggests that market participants price contractual features only at contract disclosure date, when the specific terms of trade are publicly available. This finding mitigates the concern that an omitted variable drives both the use of contractual clauses and the correlation in stock returns. Finally, we include firm fixed effects in the analyses and draw inferences from the subsample of firms that have 
contracts both with and without contractual protections. We show that the return predictability results hold only for the contracts with contractual features, even when controlling for time-invariant firm characteristics. Overall, these tests mitigate the concerns that an omitted variable drives the results.

We contribute to the literature on return predictability across economically linked firms. Cohen and Frazzini (2008) was the first paper to document that limited attention on the part of investors leads to predictable stock returns for linked firms: stock prices underreact to negative (positive) news involving related firms, which in turn generates negative (positive) subsequent price drift. Menzly and Ozbas (2010) document that the cross-predictability along the supply chain at the firm level is also present at the industry level, with equity returns of industries predicted by past equity returns of upstream and downstream industries in the United States. Shahrur, Becker, and Rosenfeld (2009) extend this analysis to developed markets around the world and also find that stock returns from downstream industries lead stock returns on supplier industries. This paper deviates from the previous literature on return predictability by integrating the role of contractual relationships between firms and their suppliers and customers. Specifically, if maintaining significant supply chain relationships increases the firm's exposure to various risks, firms should be able to design contractual relationships to mitigate some of this exposure. Investigating the role of the contractual relationship on equity return predictability is the primary contribution of our paper.

Our second contribution is to provide evidence on the channels of supply chain risk exposures. While prior studies focus only on the existence of customer-supplier links, our research setting allows us to exploit variation in exposures to financial, product, and redeployability risk. The benefit of our research setting is threefold. First, the disclosure requirements apply to both upstream and downstream relationships; thus, we are able to test whether the source of counterparty risk from suppliers differs from the source of counterparty risk from customers. Second, since firms are required to disclose sup- 
ply contracts in their entirety, we are able to test whether contractual provisions such as covenants, product warranties, relationship-specific investments, and financial exposures impact the perceived degree of counterparty risk from supply chain partners. Third, the contracts allow us to identify relationships with suppliers and customers that are material enough to influence operations and are thus likely to have a salient effect on the firm's market value.

The rest of the paper is organized as follows. We describe the sample construction in Section 2. In Section 3 we conduct an event study around press releases and contract disclosures. Section 4 demonstrates the basic return predictability results and outlines how differences in return predictability are used to test for sources of risk premia. We investigate three sources of counterparty risk in Section 5 and study the robustness of the results in Section 6. Section 7 concludes.

\section{Data}

\subsection{Sample Selection and Descriptive Statistics}

We construct our upstream and downstream relationships from material contracts filed with the SEC. Regulation S-K of the Securities Act of 1933 requires publicly filing companies to disclose supply contracts, in their entirety, as exhibits to 10-Ks, 10-Qs, or 8-Ks. Contracts must be disclosed if they represent a material portion of the filer's purchases or sales during the fiscal year. We begin by searching SEC filings for exhibits with supply or procurement in the title and buyer and supplier or seller in the first paragraph. Each resulting exhibit is checked to ensure the existence of an upstream or downstream supply agreement, and the identity of the counterparty listed in the contract is recorded. Contractual features including relationship-specific investments, product characteristics, product 
warranties, financial covenants, and trade credit terms are recorded. ${ }^{1}$ For our empirical analyses, we assume that two firms are contractually linked starting on the contract start date (the filing date or the commencement date) and ending at contract expiry. We determine contract expiry in two ways. First, we determine the contract duration from the terms of the agreement and calculate an end date based on these terms. If a contract renewal is not filed, the calculated end date is used as the contract expiry date. Second, we search $8-\mathrm{K}$ filings for contract terminations. ${ }^{2}$ If a firm reports that the contract was terminated, we use the termination date as the contract expiry date.

Each filing firm in our contract dataset is matched to CRSP/Compustat using the Central Indexing Key provided in the filing. We then hand match the counterparty to CRSP/Compustat database using the company name and location. Our sample consists of all contracts in which both counterparties are publicly listed firms with non-missing values of book equity (BE) and market equity (ME) at the fiscal quarter end for each quarter that a contractual link exists. The final sample contains 1,762 distinct firm-year relationships, representing a total of 427 unique supplier-customer relationships between 1994 and 2013.

Table 1 shows the summary statistics for the equity-matched sample. In Panel A we report the coverage of the firms in our data as a fraction of the universe of CRSP common stocks. One important feature of the sample of contracts we analyze is the relative size of the two counterparties to the contract. In contrast to Cohen and Frazzini (2008), the customers and the suppliers in our sample have a similar size distribution, which is tilted toward large cap securities: the average customer size is above the 67th percentile of CRSP firms, and the average supplier size is above the 63rd percentile of CRSP firms. This difference in the size distribution, relative to the Cohen and Frazzini (2008) sample, reflects the differences in reporting requirements. For the non-contractual relationships

\footnotetext{
${ }^{1}$ See Costello (2013) for details on the data collection procedure and a list of contractual variables collected.

${ }^{2}$ Material contract terminations are required to be disclosed under Item 1.02 of the 8-K.
} 
collected in Cohen and Frazzini (2008), firms are required to report the identity of any customer that represents more than $10 \%$ of total reported sales, which tilts the sample toward large customers. In our sample, both suppliers and customers are required to file supply contracts if the contract constitutes a material part of their business. Thus, while our sample is still tilted toward large cap stocks, the size distribution of customers and suppliers is more similar.

In Panel C, we report the sample properties of contractual features of interest. The most prevalent contractual features are financial covenants (35\% of contract-month observations on average), deferment of payment by the customer $(70 \%)$, and product warranties (54\%). In contrast, the customer extends a loan to the supplier in only $3.6 \%$ of contract-month observations on average, and only $28 \%$ of contracts require the supplier to make relationship-specific investments. It is also interesting to note that in $75 \%$ of observations, the supplier has a speculative-grade credit rating, in $80 \%$ the customer has a speculative-grade credit rating, and in $58 \%$ both counterparties to the contract have speculative-grade credit ratings.

\subsection{Determinants of Contractual Features}

As discussed in the introduction, a possible concern with our research design is that firms that have contractual protections are inherently different from firms that do not have contractual protections. For example, firms that demand financial covenant protections in their supply contracts might be more resilient to their supply chain exposures than firms that are unable to demand such protections. Therefore, an omitted variable (financial resilience) would explain the mitigated response to supply shocks rather than the inclusion of covenant protections themselves.

To shed light on this issue, we compare the characteristics of firms that have contractual protections to those that do not have contractual protections, reported in Tables 2 and 3. Contractual features that exacerbate the firm's exposure to counterparty risk in- 
clude the extension of trade credit or loans, relationship-specific investments, and contracts with speculative-grade counterparties. Therefore, we should observe more pronounced return predictability for firms that have contracts with these features. An alternative explanation for a more pronounced correlation in returns is that the firm has poor bargaining power or is financially weak; these firms may be more likely to enter contracts where they are more exposed to risk (due to their weaker bargaining power) and are thus more vulnerable to negative shocks.

The statistics reported in Table 2 do not support this alternative explanation. Firms that offer trade credit and loans and firms that make relationship-specific investments are larger, older, and more profitable than firms that do not have contracts that exacerbate counterparty risk. We also do not find any statistical differences in the relative size or the relative market power of firms in contracts with clauses that exacerbate risk versus contracts without such clauses. Overall, we conclude from Table 2 that an omitted variable related to bargaining power or financial strength is unlikely to explain our results.

In Table 3, we investigate differences in the characteristics of firms that have contractual features mitigating counterparty risk and those that do not. Contractual features that mitigate the firm's exposure to counterparty risk include financial covenants and product warranties. We expect that these features should mitigate the firm's exposure to counterparty events. An alternative explanation for a less pronounced return predictability is that the firm has stronger bargaining power or greater financial strength. If these firms are able to demand favorable contracts that protect them from risk and they are more resilient to economic shocks, our inferences could be threatened.

The statistics reported in Table 3 show that buyers that have financial covenant protections are larger and older than buyers that do not have such protections. Further, sellers that have covenant protections are marginally larger than sellers that are not protected by covenants. However, we find that firms with covenant protections have lower market shares $(\mathrm{HHI})$, and there is no significant difference in the relative size or the relative 
market power of buyers and suppliers in contracts with covenants versus contracts without covenants (Buyer/Supplier Size and Buyer/Supplier Mkt. Power). We also find that buyers that request product warranties are smaller, younger, and less profitable than buyers without warranty protections. Overall, the evidence indicates that differences in the relative market power of the contracting parties are unlikely to explain our results. To further ensure that omitted firm characteristics are not driving our results, we perform supplemental tests using firm fixed effects.

\section{Event Study}

In order for stock returns to reflect the firm's exposure to supply chain risk, two conditions must be met. First, the information needs to be available to investors, and second, the information needs to be salient enough for investors to process. Therefore, we should expect market participants to reflect the differences in the firm's relative exposure to counterparty risk only when the information about the detailed trade relationship becomes available. If market participants reflect this information before detailed trade contracts are disclosed, then either (1) details of the contract are leaked to some investors before the contract disclosure date or (2) non-contract-specific characteristics, such as the firm's market power or industry norms, explain the correlation in returns, rather than the contractual features themselves.

To explore these issues, we collect the date of the press announcement revealing that the firms are entering into a supply agreement. The press announcement typically reveals only the name of the counterparty, the product that will be exchanged, and the date that the contract will commence. Other details of the trade relationship are not available until the entire contract is disclosed in the $10 \mathrm{~K}$ at the end of the fiscal year. To collect press announcement dates, we search LexisNexis for news articles with both the buyer's and the supplier's names. We manually check the results of our search to ensure that (1) the 
press announcement refers to the contract in our sample and (2) the press announcement occurs before the contract disclosure date.

Table 4 reports the $(-2,2)$ day cumulative abnormal return for suppliers (Panel A) and customers (Panel B). For the contract filing date, we compute the abnormal return in excess of the abnormal return normally earned by the firm on $10 \mathrm{~K}$ filing dates. In columns (1) and (4) of Panels A and B, we compute abnormal returns for the event dates, controlling only for industry fixed effects. Our results indicate that there are significant abnormal returns to customers announcing their partnership with a major supplier. The abnormal returns are realized on both the press release date and the contract filing date. However, we do not document abnormal returns to suppliers that announce their partnership with a major customer. This evidence highlights one of the important contributions of our research setting: previous studies document supply chain links using the major customer database in Compustat, which provides information only about downstream relationships. However, we show that disclosing information about upstream relationships results in significant abnormal returns to the filing firm.

Next, we conduct an event study analysis of the press release date and the date that the full contract was disclosed in a public filing. If market participants use the information in contracts to identify the firm's relative exposure to counterparty risk, we should observe market reactions to contractual features only at the contract filing date, rather than at the press announcement date. Overall, we show that information about the contractual features is impounded in returns only at the contract filing date, rather than at the press release date. Suppliers that obtain loans from their customers exhibit more negative abnormal returns at the contract filing date. ${ }^{3}$ Further, customers who have covenant protections exhibit more positive abnormal returns at the contract filing date. Columns 4-6

\footnotetext{
${ }^{3}$ Our prediction regarding the direction of abnormal returns for suppliers receiving loans from customers is, ex ante, ambiguous. On one hand, receiving additional capital could be beneficial if it allows the seller to invest in positive NPV projects. On the other hand, Costello (2014) shows that sellers receiving loans are financially weak and have been rationed from traditional credit markets. If the loan provides information to investors on the financial health of suppliers, the return could be negative.
} 
report that none of the contractual features impact the firm's returns on the press release date. ${ }^{4}$ The evidence provided in Table 4 is consistent with our prediction that investors are responding to information about the specific contractual terms, rather than to more general information about the buyer-supplier link.

\section{Return Predictability, Limited Attention, and Counter- party Risk}

In this Section, we describe how return predictability can be used to test which channels of counterparty risk are priced in market returns. Under the limited attention hypothesis of Cohen and Frazzini (2008), stock prices underreact to information about related firms, creating return predictability across assets. Investors' limited attention has implications for return predictability if two conditions are satisfied: information overlooked by investors is both salient and available before prices evolve. In this paper, we argue that contractual features that reduce counterparty risk also reduce the saliency of information about linked firms for the firm's own stock return. Thus, by testing the impact of contractual features on return predictability, we can identify whether different sources of counterparty risk command a risk premium.

To test for return predictability, we study quarterly returns on calendar-time portfolios formed by sorting stocks on their lagged counterparty returns. We consider two strategies: one based on the transmission of shocks from customers to their suppliers, "upstream momentum," and one based on the transmission of shocks from suppliers to their customers, "downstream momentum." Since some firms in our sample have multiple customers (suppliers) over many periods, we construct the customer (supplier) return for

\footnotetext{
${ }^{4} \mathrm{We}$ omit the indicator for the speculative-grade counterparty in Panel A because for the press release sample, all of the customers are of speculative-grade. In Column 6 of Panel A, the loan indicator is omitted as all of the suppliers for whom we have balance sheet information (EBITDA and sales) do not receive loans from their customers.
} 
a given firm as the equal-weighted portfolio return of all the customers (suppliers) of the firm at a given date. At the beginning of each month, we rank stocks in ascending order based on the customer (supplier) returns between months $t-4$ and $t-1$ and assign them to one of five quintile portfolios. All stocks are value-weighted within a given portfolio, and the portfolios are rebalanced every calendar month to maintain value weights.

We construct the downstream (upstream) momentum strategy as the zero-cost portfolio that holds the top $20 \%$ of high-customer (supplier)-return stocks and sells short the bottom $20 \%$ of low-customer (supplier)-return stocks. Since these investment rules are based entirely on observable, lagged returns, they should earn zero abnormal returns in a fully efficient market. On the other hand, positive portfolio abnormal returns in excess of traded factor exposure following positive customer (supplier) returns are indicative of the presence of upstream (downstream) momentum and, hence, indicate underreaction to news about linked firms. Since the opposite is true for negative news, a long-short portfolio that sorts on customer (supplier) news should generate positive returns.

In Table 5, we report the average excess return to the long-short upstream (Panel A) and downstream (Panel B) momentum strategies. While the upstream momentum strategy generates significant returns, with Fama and French (1993) abnormal returns of 1.84\% per quarter or approximately $7.5 \%$ per year, the returns to the downstream momentum strategy are much smaller and are not statistically significant. Adjusting the returns of the upstream momentum strategy by augmenting the factor model with the Carhart (1997) momentum factor and the traded liquidity factor of Pastor and Stambaugh (2003) has a negligible effect on the results: the abnormal return on the long-short portfolio is $1.81 \%$ for the four factor model at a quarterly horizon and $1.88 \%$ for the five factor model. The results show that, even after controlling for past returns or a reversal measure of liquidity, high (low) upstream momentum stocks earn high (low) risk-adjusted subsequent returns.

There are two potential (not mutually exclusive) explanations for the failure of the downstream momentum strategy to generate significant returns: either the investors re- 
act in a timely manner to news about a firm's suppliers (so that the information is incorporated immediately into the firm's stock return), or investors are unaware of the suppliers of the firm (so that the information about the supplier is never incorporated into the stock return). The results in Section 5 give credence to the former explanation, since downstream momentum is present when the contract does not protect the customer from exposure to the supplier. It is worth noting that, although the downstream momentum strategy does not generate statistically significant returns, augmenting the factor model with the Carhart (1997) momentum factor and the Pastor and Stambaugh (2003) liquidity factor has little effect in this case as well: the abnormal return on the long-short downstream portfolio is $0.59 \%$ for the four factor model and $1.19 \%$ for the five factor model.

The last column of Table 5 tests whether all of the excess returns to the long-short strategies are generated persistently by the same firms by including firm fixed effects. The inclusion of supplier fixed effects in the upstream momentum strategy increases the five factor alpha to $1.95 \%$ but does not impact the significance of the point estimate. Similarly, the inclusion of customer fixed effects in the downstream momentum strategy increases the five factor alpha to $1.56 \%$. Thus, for a given supplier, market participants demand additional compensation for risk during months when the supplier's customers underperform and less compensation for risk during months when the customers outperform the customers of other suppliers.

We conclude this Section by investigating whether market participants perceive shocks from contractually linked counterparties to be more detrimental than shocks from non contractually linked counterparties. We merge our dataset of contractually linked counterparties with the major customer dataset used by Cohen and Frazzini (2008) and assume that any link not present in our dataset is non contractual. We test for the impact of a contractual link by estimating the following model:

$$
r x_{t}=\alpha_{0}+\alpha_{1} \mathbf{1}_{\text {Contract }}+\sum_{i}\left(\beta_{i 0} F F_{i t}+\beta_{i 1} F F_{i t} \times \mathbf{1}_{\text {Contract }}\right)+\epsilon_{t}
$$


where $r x_{t}$ is the portfolio return in excess of the risk-free rate in month $t, \mathbf{1}_{\text {Contract }}$ is the indicator variable of whether the relationship is contractual, $F F_{i t}$ is the return on the $i^{\text {th }}$ hedging factor, and $F F_{i t} \times \mathbf{1}_{\text {Contract }}$ is the interaction between the factor return and the contract indicator variable. If contracts make customer-supplier relationships harder to terminate, return predictability will be higher for relationships created through contracts. Thus, $\alpha_{1}$ should be positive.

Table 6 reports the returns for the upstream momentum (Panel A) and downstream momentum (Panel B) strategies, controlling for whether the relationship is contractual. The existence of a contract between the two counterparties generates significant increases in the returns to the upstream momentum strategy, with the Fama and French (1993) abnormal return $2.11 \%$ points higher for contractually linked counterparties. As with the baseline momentum strategy of Table 5, adjusting the returns of the upstream momentum strategy by augmenting the factor model with the Carhart (1997) momentum factor and the traded liquidity factor of Pastor and Stambaugh (2003) has a negligible effect on the results: having a contractual relationship raises the four factor alpha by $2.03 \%$ and the five factor alpha by $2.05 \%$ per quarter. Finally, the last column of Table 6 shows that return predictability is higher when the shocks originate from contractually linked customers, even after controlling for supplier fixed effects. This suggests that for suppliers that have both contractual customers and non-contractual customers, return predictability manifests only through contractual links.

Panel B shows that all of the returns to the downstream momentum strategy are earned from contractually linked firms (although the point estimate is insignificant). The point estimate on the contract indicator, however, does not change significantly when we include the Carhart (1997) momentum factor, the traded liquidity factor of Pastor and Stambaugh (2003), or customer fixed effects in the regression specification.

To summarize, the results of this section show that market participants demand compensation for the risk of shock transmission between trading partners. This compensation 
is higher when the shock is transmitted from customers to suppliers (upstream momentum) and if the two counterparties are linked through a contract. Thus, although there are beneficial aspects of product market relationships, there are also costs associated with the large legal obligations created through long-term contracts. In the rest of the paper, we examine how contracts can be designed to mitigate these adverse effects.

\section{Sources of Counterparty Risk}

\subsection{Financial exposure and credit risk}

We begin by examining whether greater financial exposure through long-term contracts is priced in the equity market. As shown in Jorion and Zhang (2009), unsecured claim holders of defaulting firms experience negative abnormal equity returns and increased CDS spreads following the credit default of major counterparties. In this section, we examine whether this adverse effect on the firm's equity is priced ex ante. We consider three sets of proxies for financial exposure through supply contracts: whether the contract contains financial covenants, whether trade credit is extended, and whether the counterparty has a speculative-grade credit rating.

Costello (2013) shows that financial covenants are used in long-term supply contracts as early warning signs of a partner's financial distress. The most common covenants used in supply contracts require the contracting parties to maintain minimum levels of net worth or net income; such performance requirements mitigate financial exposure because covenant violations allow the non defaulting party to demand immediate repayment or to exit the contract. Therefore, financial covenants allow firms to collect their claims before becoming an unsecured claim holder in the event that their supply partner enters default. 
We test for the impact of financial covenants by estimating the following model:

$$
r x_{t}=\alpha_{0}+\alpha_{1} \mathbf{1}_{\text {Fin. Covenant }}+\sum_{i}\left(\beta_{i 0} F F_{i t}+\beta_{i 1} F F_{i t} \times \mathbf{1}_{\text {Fin. Covenant }}\right)+\epsilon_{t}
$$

where $r x_{t}$ is the portfolio return in excess of the risk-free rate in month $t, \mathbf{1}_{\text {Fin. Covenant }}$ is the indicator variable of whether the contract includes financial covenants, $F F_{i t}$ is the return on the $i^{\text {th }}$ hedging factor, and $F F_{i t} \times \mathbf{1}_{\text {Fin. Covenant }}$ is the interaction between the factor return and the financial covenant indicator variable. If financial covenants mitigate a dimension of counterparty risk that is priced in equity returns, then return predictability will be lower for relationships based on contracts with financial covenants. Thus, $\alpha_{1}$ should be negative, and $\alpha_{0}$ should be positive.

Table 7 reports the returns for the upstream momentum (Panel A) and downstream momentum (Panel B) strategies, controlling for the presence of financial covenants in the contract. When the contract does not include financial covenants, the upstream momentum strategy generates positive and significant returns, with Fama and French (1993) abnormal returns of $3.3 \%$ per quarter or approximately $15 \%$ per year. The inclusion of financial covenants in the contract lowers this return by $4.5 \%$ per quarter, which is both economically and statistically significant. Augmenting the factor model with the Carhart (1997) momentum factor, the Pastor and Stambaugh (2003) liquidity factor, and supplier fixed effects has a negligible effect on the results: the abnormal return on the long-short portfolio of contracts without financial covenants is $2.8 \%$ for the five factor model with supplier fixed effects at a quarterly horizon, and the inclusion of covenants lowers that return by $4.3 \%$. Thus, even though high (low) upstream momentum stocks earn high (low) risk-adjusted subsequent returns, the inclusion of financial covenants dramatically reduces these returns. These results suggest that equity markets perceive financial covenants as mitigating upstream counterparty risk. Because many suppliers have both contracts with and contracts without covenants, we are able to include firm 
fixed effects to capture within-firm variation in the contribution of covenants to counterparty risk. The results in column 5 indicate that firms are less exposed to risk only for their contracts with covenants.

Panel B of Table 7 shows that the downstream momentum strategy also generates significant returns: in the absence of financial covenants, the downstream momentum strategy has Fama and French (1993) abnormal returns of 2.03\% per quarter or approximately $8.4 \%$ per year. The inclusion of financial covenants reduces that abnormal return by $3.03 \%$ per quarter, which is both economically and statistically significant. Thus, the absence of financial covenants is a priced source of risk for downstream momentum strategies, implying that market participants believe that financial covenants mitigate downstream counterparty risk. These results hold even after we augment the factor model with the Carhart (1997) momentum factor, the Pastor and Stambaugh (2003) liquidity factor, and customer fixed effects: the abnormal return on the long-short portfolio of contracts without financial covenants is $3.1 \%$ for the five factor model with customer fixed effects, and the inclusion of covenants lowers that return by $3.06 \%$.

Next, we analyze the impact of financial exposure on return predictability using the terms of trade credit established in the contract. We investigate whether exposures through trade credit are priced ex ante in equity returns. ${ }^{5}$ Trade credit represents the financing terms associated with the exchange of goods and services. For the contracts in the sample, trade financing can take three forms: deferrals, advances, and loans. Deferrals allow the customer to purchase goods or services from suppliers on account, with the ability to pay at a later date. Deferrals can increase the firm's exposure to its customers' credit risk since suppliers become unsecured creditors in the event of a customer default. Advances provide funds to suppliers before the delivery of goods, and the liability is settled upon product delivery. Therefore, advances can increase the firm's exposure to its supplier's

\footnotetext{
${ }^{5}$ Jorion and Zhang (2009) find that, for non financial firms, when a creditor unexpectedly defaults, a $1 \%$ exposure in market equity terms is associated with a roughly $1 \%$ wealth loss for the non defaulting counterparty.
} 
credit risk if the supplier defaults before product delivery. Finally, loans provide general purpose financing to suppliers with the promise to pay the customer the principal and interest at a future date. Costello (2014) finds that firms extend loans to their suppliers for large capital expenditures necessary for the trade relationship, including specialized equipment and manufacturing facilities. The average repayment period for loans is three years. Loans increase the firm's exposure to its suppliers' credit risk over the repayment period.

We test for the impact of trade credit by estimating the following model:

$$
r x_{t}=\alpha_{0}+\alpha_{1} \mathbf{1}_{\text {Trade Credit }}+\sum_{i}\left(\beta_{i 0} F F_{i t}+\beta_{i 1} F F_{i t} \times \mathbf{1}_{\text {Trade Credit }}\right)+\epsilon_{t},
$$

where $\mathbf{1}_{\text {Trade }}$ Credit is the indicator of trade credit extended to the counterparty, $r x_{t}$ is the portfolio return in excess of the risk-free rate in month $t$, and $F F_{i t}$ is the return on the $i^{\text {th }}$ hedging factor. If financial exposure through trade credit commands an equity risk premium, $\alpha_{1}$ and $\alpha_{0}+\alpha_{1}$ should be positive, so that increased exposure increases the impact of negative news about customers or suppliers on the firm's return.

Panel A of Table 8 reports the returns for the upstream momentum strategy, controlling for whether the payment from the customer to the supplier is deferred past the delivery date of the product. If payment deferral increases the seller's risk exposure, we expect it to affect the upstream momentum strategy. We do not find statistical support for this prediction in any of the specifications estimated. In Panel B of Table 8, we report the impact of payment advances on the downstream momentum strategy. If advances increase the firm's exposure to supplier risk, we would expect more significant returns to the downstream momentum strategy for firms advancing funds to their sellers. We do not find statistically significant differences between exposures with trade credit advances versus exposures without trade credit advances. The results in Panels A and B suggest that trade credit exposures through deferrals and advances do not contribute to signifi- 
cant differences in counterparty risk. We hypothesize that the trade credit exposures for our sample are, on average, small or short in duration, which would mitigate negative spillovers.

In Panel C, we report the returns for the downstream momentum strategy, controlling for whether the customer extends a loan to the supplier. ${ }^{6}$ While loans are relatively infrequent in our sample, the large financial exposure they create has a significant impact both economically and statistically — on the return the strategy that holds the top 50\% high supplier return stocks and sells short the bottom $50 \%$ low supplier return stocks. The Fama and French (1993) abnormal return to the downstream momentum strategy is $7.6 \%$ higher for contracts that feature a loan to the supplier. Augmenting the factor model with the Carhart (1997) momentum factor, the Pastor and Stambaugh (2003) liquidity factor, and customer fixed effects changes the point estimate of the effect but not its significance: extending a loan to the supplier raises the five factor alpha, controlling for customer fixed effects, by $10.9 \%$ per quarter. We note that most of the effect comes from the adverse impact on the abnormal return of the short leg of the portfolio: the abnormal return to holding the bottom $50 \%$ low supplier return stocks is $10.7 \%$ lower when the customer extends a loan to the supplier. Since the trade creditor is an unsecured claimant in bankruptcy, exposure through loans to suppliers with poor returns adversely affects the customers' equity return.

Finally, we test whether financial exposures impact counterparty risk using information on the supply partners' credit ratings. Specifically, trading with supply partners that have speculative-grade credit ratings should expose the firm to greater financial risk since these firms have a higher probability of defaulting on their debt obligations. Since the trade creditor becomes an unsecured claimant in bankruptcy, trading with speculativegrade firms increases financial exposure, relative to trading with investment-grade firms.

\footnotetext{
${ }^{6}$ We omit the results for the upstream momentum strategy for brevity. Consistent with the theoretical predictions, loans to the supplier do not affect the returns to the upstream momentum strategy.
} 
We test for the impact of credit risk by estimating the following model:

$$
r x_{t}=\alpha_{0}+\alpha_{1} \mathbf{1}_{\text {Speculative Grade }}+\sum_{i}\left(\beta_{i 0} F F_{i t}+\beta_{i 1} F F_{i t} \times \mathbf{1}_{\text {Speculative Grade }}\right)+\epsilon_{t},
$$

where $\mathbf{1}_{\text {Speculative Grade }}$ is an indicator equal to one if the counterparty has a speculativegrade credit rating (below BBB- on the $\mathrm{S} \& \mathrm{P}$ scale), $r x_{t}$ is the portfolio return in excess of the risk-free rate in month $t$, and $F F_{i t}$ is the return on the $i^{\text {th }}$ hedging factor. If exposure to credit risk commands an equity risk premium, $\alpha_{1}$ and $\alpha_{0}+\alpha_{1}$ should be positive, so that increased exposure increases the impact of negative news about customers or suppliers on the firm's return.

Table 9 reports the returns for the upstream momentum (Panel A) and downstream momentum (Panel B) strategies, controlling for whether the customer (supplier) has a speculative-grade credit rating. Neither the upstream nor the downstream momentum strategy generates significant returns after controlling for the counterparty's credit quality, even after augmenting the factor model with the Carhart (1997) momentum factor, the Pastor and Stambaugh (2003) liquidity factor, and firm fixed effects. In unreported results, we exploit variation in the relative credit quality of the supply chain partners. Specifically, we test whether contracting with a counterparty whose credit rating is lower than the firm's increases the abnormal return to the upstream or downstream momentum strategies. We find that the effect for the upstream momentum strategy is positive and statistically significant; for the downstream momentum strategy, the effect is positive but not statistically significant. ${ }^{7}$ Thus, overall, investors in the equity market perceive contracts with lower quality counterparties as increasing firms' exposures to credit risk and are paid a risk premium for exposure to firms with lower rated counterparties. This is consistent with an ex ante pricing of the negative return experienced by unsecured creditors of defaulting firms.

\footnotetext{
${ }^{7}$ The results for an investment-grade firm contracting with a speculative-grade counterparty are qualitatively similar.
} 


\subsection{Product quality risk}

Next, we examine whether exposure to product quality risk is priced in the equity market. Firms can be exposed to product quality risk because their suppliers are better informed about the quality of inputs and effort used in production. If it is costly for managers to distinguish between high quality and low quality producers, the low quality suppliers have incentives to shirk on quality. Exposure to this type of risk can result in significant losses to the firm. For example, Hortaçsu, Matvos, Syverson, and Venkataraman (2013) find that automobile prices are significantly lower when suppliers cannot provide high quality service parts and maintenance. One way to curtail these costs is to purchase product warranties, which provide guarantees of product quality by granting the purchaser insurance against product defects.

Warranties can reduce product quality concerns in two ways. Spence (1977) argues that warranties serve a signaling role; high quality producers offer full insurance since their products are unlikely to break down. Therefore, customers can differentiate between high and low quality suppliers ex ante. Second, warranties promise a high level of product quality that is ex post verifiable. This verifiability reduces the suppliers' incentives to shirk ex post (Kambhu, 1982; Cooper and Ross, 1985). Based on these arguments, we expect that firms entering contracts with product warranties are less exposed to product quality risk than those entering contracts without product warranties.

In Table 10, we test for the impact of product warranties by estimating the following model:

$$
r x_{t}=\alpha_{0}+\alpha_{1} \mathbf{1}_{\text {Product Warranty }}+\sum_{i}\left(\beta_{i 0} F F_{i t}+\beta_{i 1} F F_{i t} \times \mathbf{1}_{\text {Product Warranty }}\right)+\epsilon_{t},
$$

where $\mathbf{1}_{\text {Product Warranty }}$ is the indicator variable equal to one if a product warranty is included in the contract, $r x_{t}$ is the portfolio return in excess of the risk-free rate in month $t$, and $F F_{i t}$ is the return on the $i^{t h}$ hedging factor. If product warranties mitigate expo- 
sure to quality risk and product risk is priced in equity returns, then return predictability will be lower for relationships based on contracts with product warranties. Since product warranties protect the customer only, the inclusion of product warranties should impact the profitability of the downstream momentum strategy only. Thus, for the upstream momentum strategy, $\alpha_{0}$ should be positive and $\alpha_{1}$ should be zero. For the downstream momentum strategy, $\alpha_{1}$ should be negative and $\alpha_{0}+\alpha_{1}$ should be close to zero.

Consistent with predictions, Panel A of Table 10 shows that product warranties do not affect the upstream momentum strategy. Since product warranties only protect the customer from product risk, they do not mitigate or exacerbate upstream momentum. In Panel B of Table 10, we show that product warranties do have a significant effect on the profitability of the downstream momentum strategy. The Fama and French (1993) abnormal return to the downstream momentum strategy for customers not protected by product warranties is $1.64 \%$ per quarter, whereas the downstream momentum strategy for customers with product warranties decreases the return by $2.19 \%$. Thus, the absence of product warranties is a priced source of risk for downstream momentum strategies, implying that market participants believe that product warranties mitigate input product risk. These results hold even after we augment the factor model with the Carhart (1997) momentum factor, the Pastor and Stambaugh (2003) liquidity factor, and customer fixed effects: the abnormal return on the long-short downstream portfolio of contracts without product warranties is $2.79 \%$ for the five factor model with fixed effects. The inclusion of product warranties reduces the five factor abnormal return by $2.69 \%$ per quarter, with both coefficients statistically significant.

It is important to note that financial covenants can also mitigate the risk of moral hazard related to product quality. Maksimovic and Titman (1991) show that financial distress may cause suppliers to shirk on product quality. Similarly, theory of the firm (Jensen and Meckling, 1976) suggests that borrowers are likely to engage in risk-shifting when financial distress becomes more likely. Financial covenants counteract these incentives 
by transferring decision rights to the non defaulting party in states of the world where incentive conflicts are high (Aghion and Bolton, 1992). Costello (2013) finds that financial covenants are more likely to be used to monitor counterparties when information asymmetry between customers and suppliers is high. The results of Table 7 are consistent with this interpretation as well, with financial covenants protecting customers from potential moral hazard on the part of their suppliers and vice versa.

\subsection{Redeployability risk}

The final source of counterparty risk that we address is the redeployability of assets. Redeployability risk arises when it is difficult to find alternative trade partners in the event that a linked party enters distress. We use two proxies to capture redeployability risk: first, if the exchange between buyers and suppliers involves investments in relationshipspecific assets (RSIs), it becomes more costly to find alternative trade partners. Second, if the counterparty operates in a concentrated industry, there are fewer substitute trade partners available.

Sunk investments in specific assets increase the costs associated with finding a replacement partner and thus increase the exposure of the investing party to the performance of its counterparty. For example, Samsung Electronics is the primary provider of

electronic chips for Apple's iPads and iPhones. The large volume of Apple ARM chip orders required that Samsung dramatically increase their investment in chip manufacturing plants. The investments related to Apple-specific chip manufacturing increase Samsung's exposure to Apple's performance.

To capture RSIs, we determine the capital requirements, if any, from the supply contract. The contract provides information about capital requirements including property, plant, and machinery additions or improvements required to fill orders. The contract also provides information on which party to the contract funds these investments; therefore, we classify RSIs as customer-specific or supplier-specific. We predict that a customer- 
specific RSI will increase the customer's exposure to their supplier's risk, and a supplierspecific RSI will increase the supplier's exposure to their customer's risk.

We test for the impact of RSIs by estimating the following model:

$$
r x_{t}=\alpha_{0}+\alpha_{1} \mathbf{1}_{\text {Investment }}+\sum_{i}\left(\beta_{i 0} F F_{i t}+\beta_{i 1} F F_{i t} \times \mathbf{1}_{\text {Investment }}\right)+\epsilon_{t},
$$

where $\mathbf{1}_{\text {Investment }}$ is an indicator variable equal to one if the firm invested in a contractually specified RSI. If equity market participants perceive RSIs as increasing redeployability risk, then $\alpha_{1}$ should be positive.

Table 11 reports the returns for the upstream momentum (Panel A) and downstream momentum (Panel B) strategies, controlling for whether the contract includes relationshipspecific investment. Consistent with predictions, we find a positive coefficient on the investment indicator. In particular, the Fama and French (1993) abnormal return to the upstream momentum strategy when the supplier does not invest in relationship-specific assets is $-6.7 \%$ per quarter, which increases by $7.63 \%$ when the supplier does invest. That is, nearly all of the return to the unconditional upstream momentum strategy is earned from contracts in which the supplier is exposed to redeployability risk. The economic magnitude and the statistical significance of this result is little changed when we augment the factor model with the Carhart (1997) momentum factor, the Pastor and Stambaugh (2003) liquidity factor, and supplier fixed effects: the abnormal return is $-5.75 \%$ when the supplier does not invest and increases by $7.2 \%$ when the supplier does invest. Panel B shows that the results for the downstream momentum strategy are qualitatively similar, although the point estimates of the coefficients are not statistically significant. The Fama and French (1993) abnormal return to the downstream momentum strategy when the customer does not invest in RSIs is $-2.3 \%$ per quarter, which increases by $6.86 \%$ when the supplier does invest.

Next, we develop a measure of the costliness of switching to an alternative trade part- 
ner based on the concentration index of the counterparty's industry. This measure captures the potential for the firm to find a replacement trade partner. For example, if the firm sells to customers in a concentrated industry, we predict that the firm is more exposed to counterparty risk since there are fewer opportunities to find alternative customers. This measure, however, is not unambiguous; a firm operating in a concentrated industry may be more resilient to shocks if, by exercising oligopolistic power, it can pass along losses to its end customers rather than to its trading partners.

In Table 12, we test for the impact of contracting with a counterparty in a concentrated industry by estimating the following model:

$$
r x_{t}=\alpha_{0}+\alpha_{1} \mathbf{1}_{\text {High HHI }}+\sum_{i}\left(\beta_{i 0} F F_{i t}+\beta_{i 1} F F_{i t} \times \mathbf{1}_{\text {High HHI }}\right)+\epsilon_{t},
$$

where $\mathbf{1}_{\text {High HHI }}$ equals one if the counterparty belongs to an industry in the upper 50 th percentile of the distribution of industry-level Herfindahl indexes within a given month, and zero otherwise. If contracting with a firm in a high concentration industry leads to redeployability concerns, $\alpha_{1}$ and $\alpha_{0}+\alpha_{1}$ should be positive. Panel A of Table 12 shows that contracting with a customer in a highly concentrated industry lowers the five factor abnormal return to the upstream momentum strategy by $5.61 \%$, consistent with the notion that customers with more market power can choose to impose losses on their customers instead of their suppliers. This effect is both economically and statistically significant; the five factor alpha on the upstream momentum strategy for firms contracting with customers in non concentrated industries is 5.82\% per quarter. The results in Panel B show that firms contracting with suppliers in concentrated industries do not generate statistically different return predictability than those that contract with suppliers in non concentrated industries.

Overall, we provide some evidence that redeployability risk impacts the firm's exposure to its supply chain partners. The primary channel through which redeployability 
risk impacts returns is investments in RSIs. ${ }^{8}$

\section{Robustness Tests}

\subsection{Non-overlapping returns}

Table 13 reports the five factor abnormal returns including fixed effects on the long-short momentum strategies computed using non-overlapping observations of returns. More specifically, at the beginning of each quarter $t$, we rank stocks in ascending order based on the customer's (supplier's) returns over quarter $t-1$ and assign them to one of five quintile portfolios. All stocks are value-weighted within a given portfolio, and the portfolios are rebalanced every calendar quarter to maintain value weights.

Panel A of Table 13 shows that the unconditional upstream momentum strategy still generates positive abnormal returns when non-overlapping returns are used. Consistent with the results for the sample of overlapping returns, the presence of financial covenants lowers the quarterly return by $4.2 \%$, which is both economically and statistically significant. The other contractual features do not retain the significance of the corresponding coefficients, although the point estimates remain largely unchanged. Thus, for example, deferred payments to the suppliers earn a positive risk premium, and contracting with customers in a highly concentrated industry earns a negative risk premium.

In Panel B of Table 13, we see that the five factor abnormal return on the downstream momentum strategy is larger than in the overlapping sample specification, with abnormal returns of around $1.6 \%$ per quarter for the unconditional strategy. For contracts in which the customer extends a loan to the supplier, the abnormal return increases by $7.05 \%$ per quarter, which is both economically and statistically significant. Likewise, product warranties decrease the transmission of shocks from suppliers to customers, with an abnor-

\footnotetext{
${ }^{8}$ In unreported analyses, we include other measures of exposure to redeployability risk including the Rauch (1999) product differentiation and input differentiation indices. We do not find that inclusion of these indices has a significant impact on the firm's abnormal returns.
} 
mal return on the long-short strategy that is $5.8 \%$ lower for contracts with product warranties in place. Overall, these results suggest that contracting features mitigate shock transmission between counterparties even if we measure the transmission channel using non-overlapping returns.

\subsection{Falsification test}

In order to rule out the possibility that return predictability is a function of linked cash flows absent contractual relationships, we test whether the predictability of returns is present before the two counterparties enter into a contract. At the beginning of each calendar month $t$, we rank stocks in ascending order based on the returns over months $t-4$ to $t-1$ of their future customers (suppliers) and assign them to one of five quintile portfolios. All stocks are value-weighted within a given portfolio, and the portfolios are rebalanced every month to maintain value weights. We construct the downstream (upstream) momentum strategy as the zero-cost portfolio that holds the top $20 \%$ of high-customer (supplier)-return stocks and sells short the bottom $20 \%$ of low-customer (supplier)-return stocks. Table 14 reports the five factor abnormal returns to this long-short strategy.

Panel A shows that, as predicted, the upstream momentum strategy fails to yield significant returns before the two parties enter into a contract. More importantly, characteristics of the future contract do not produce a significant spread in returns. Similarly, Panel B shows that the downstream momentum strategy does not generate significant returns before the two parties enter into a contract and that characteristics of the future contract do not produce a significant spread in returns.

\section{Conclusion}

This paper provides evidence that the design of supply contracts can mitigate the exposure of parties to the contract to their counterparties' risk events. Comparing contractual 
to non contractual links, we find that shocks are transmitted only through contractual links, consistent with contracts creating large legal obligations between the two parties. The unique feature of our setting is that we observe detailed contractual features of the links between customers and suppliers, allowing us to disentangle the specific channels of shock transmission. We provide evidence that financial covenants and product warranties mitigate shock transmission, while trade credit and RSIs exacerbate the transmission of shocks. Finally, we show that equity markets efficiently incorporate the information about contractual features when it becomes publicly available.

More broadly, while the prior literature has documented the beneficial aspects of close product market relationships, we show that there are also costs associated with longterm relationships. Indeed, Bodnar, Giambona, Graham, Harvey, and Marston (2011) find that $38 \%$ of risk managers cite long-term contracts with customers as the most significant form of credit risk faced, and $23 \%$ cite long-term contracts with suppliers. We provide evidence that managers can design contracts to mitigate these risks and are rewarded for well designed contracts by equity market participants. 


\section{References}

AGHiON, P. AND P. BOLTON (1992): “An incomplete contracts approach to financial contracting," The Review of Economic Studies, 59, 473-494.

Allen, J. W. AND G. M. Phillips (2000): “Corporate equity ownership, strategic alliances, and product market relationships," The Journal of Finance, 55, 2791-2815.

BiAis, B. AND C. GOLliER (1997): "Trade credit and credit rationing," Review of Financial Studies, 10, 903-937.

Bodnar, G., E. Giambona, J. Graham, C. HARvey, And R. MARston (2011): “Managing Risk Management," Working paper.

BOONE, A. L. AND V. I. IVANOV (2012): "Bankruptcy spillover effects on strategic alliance partners," Journal of Financial Economics, 103, 551-569.

CARHART, M. M. (1997): “On persistence in mutual fund performance," Journal of Finance, 52, 57-82.

Chan, S. H., J. W. Kensinger, A. J. KeOWN, And J. D. Martin (1997): “Do strategic alliances create value?" Journal of Financial Economics, 46, 199-221.

COHEN, L. AND A. FRAZZIni (2008): “Economic Links and Predictable Returns," Journal of Finance, 63, 1977-2011.

COOPER, R. AND T. W. Ross (1985): "Product warranties and double moral hazard," The RAND Journal of Economics, 103-113.

Costello, A. M. (2013): "Mitigating incentive conflicts in inter-firm relationships: Evidence from long-term supply contracts," Journal of Accounting and Economics, 56, 19-39.

(2014): "Trade Credit Policy in Long-Term Supply Contracts," Working paper, SSRN Abstract No. 2379118.

FAMA, E. F. AND K. R. FRENCH (1993): "Common risk factors in the returns on stocks and bonds," Journal of Financial Economics, 33, 3-56.

HENDRICKS, K. B. AND V. R. Singhal (2003): “The effect of supply chain glitches on shareholder wealth," Journal of Operations Management, 21, 501-522.

Hertzel, M. G., Z. Li, M. S. OfFicer, AND K. J. Rodgers (2008): “Inter-firm linkages and the wealth effects of financial distress along the supply chain," Journal of Financial Economics, 87, 374-387.

Hortaçsu, A., G. Matvos, C. Syverson, and S. Venkataraman (2013): “Indirect Costs of Financial Distress in Durable Goods Industries: The Case of Auto Manufacturers," Review of Financial Studies, 26, 1248-1290. 
Jensen, M. C. AND W. H. MeCKLING (1976): “Theory of the firm: Managerial behavior, agency costs and ownership structure," Journal of Financial Economics, 3, 305-360.

JORION, P. AND G. ZHANG (2009): “Credit Contagion from Counterparty Risk," The Journal of Finance, 64, 2053-2087.

KAMBHU, J. (1982): “Optimal product quality under asymmetric information and moral hazard," The Bell Journal of Economics, 483-492.

MaKsimovic, V. And S. Titman (1991): "Financial Policy and Reputation for Product Quality," Review of Financial Studies, 4, 175-200.

MenZly, L. AND O. OzbAS (2010): "Market Segmentation and Cross-predictability of Returns," The Journal of Finance, 65, 1555-1580.

PASTOR, L. AND R. F. STAMBAUGH (2003): “Liquidity Risk and Expected Stock Returns," Journal of Political Economy, 111.

Petersen, M. A. AND R. G. Rajan (1997): “Trade Credit: Theories and Evidence," Review of Financial Studies, 10, 661-691.

RAUCH, J. E. (1999): “Networks versus markets in international trade," Journal of International Economics, 48, 7-35.

SHAHRUR, H., Y. L. BECKER, AND D. RosenfELD (2009): “Return predictability along the supply chain: the international evidence," Working paper, Bentley University and State Street Global Advisors.

SPENCE, M. (1977): “Consumer Misperceptions, Product Failure and Producer Liability," Review of Economic Studies, 44.

Titman, S. (1984): “The effect of capital structure on a firm's liquidation decision," Journal of Financial Economics, 13, 137-151. 
Table 1: Summary Statistics. Summary statistics for contracts where both counterparties have commonly traded equity. "Speculative-grade" refers to firms rated below BBB- by S\&P. Source: SEC filings, CRSP, Mergent.

\begin{tabular}{|c|c|c|c|c|c|}
\hline & Min & $\operatorname{Max}$ & Mean & $S D$ & Median \\
\hline \multicolumn{6}{|c|}{ Panel A: Time Series (22 annual observations, 1993 - 2014) } \\
\hline Number of contracts in the sample & 14 & 233 & 163.2 & 63.7 & 186.0 \\
\hline Number of unique & 7 & 131 & 89.6 & 36.0 & 103.5 \\
\hline Number of unique suppliers per year & 7 & 134 & 91.6 & 37.7 & 106 \\
\hline (EW) & 0.1 & 1.7 & 1.1 & 0.5 & 1.3 \\
\hline Cust & 0.1 & 1.8 & 1.2 & 0.5 & 1.3 \\
\hline over & 0.2 & 13.6 & 6.8 & 3.4 & 7.8 \\
\hline coverage (VW) & 0.2 & 13.4 & 6.8 & 3.1 & 7.4 \\
\hline \multicolumn{6}{|c|}{ Panel B: Firms (Pooled Firm-Year Observations) } \\
\hline Sup & 1 & 100 & 61.7 & 30.3 & 68 \\
\hline $\mathrm{Cu}$ & 1 & 100 & 63.6 & 29.5 & 70 \\
\hline ok-to-market per & 2 & 100 & 41.0 & 26.8 & 36 \\
\hline Customer book-to-market percentile & 1 & 100 & 40.1 & 26.8 & 34 \\
\hline \multicolumn{6}{|c|}{ Panel C: Contracts Time Series (22 annual observations, 1993 - 2014) } \\
\hline$\%$ of $\mathrm{c}$ & 23.5 & 44.4 & 37.6 & 6.6 & 39.7 \\
\hline$\%$ of contracts with loa & 1.1 & 5.1 & 2.6 & 1.3 & 2.3 \\
\hline$\%$ of contracts with pa & 52.3 & 100.0 & 67.3 & 11.7 & 63.2 \\
\hline tracts with speculati & 75.7 & 90.6 & 84.2 & 3.6 & 85.2 \\
\hline$\%$ of contracts with speculati & 63.9 & 85.7 & 77.1 & 4.3 & 77.1 \\
\hline$\%$ of contracts with both spec & 44.4 & 71.4 & 62.9 & 6.2 & 64.1 \\
\hline racts with product wi & 28.6 & 68.9 & 54.3 & 9.2 & 53.7 \\
\hline$\%$ of contracts with customer investing & 0.7 & 4.0 & 2.5 & 0.9 & 2.5 \\
\hline$\%$ of contracts with supplier investing & 14.3 & 52.8 & 28.2 & 9.6 & 27.3 \\
\hline
\end{tabular}




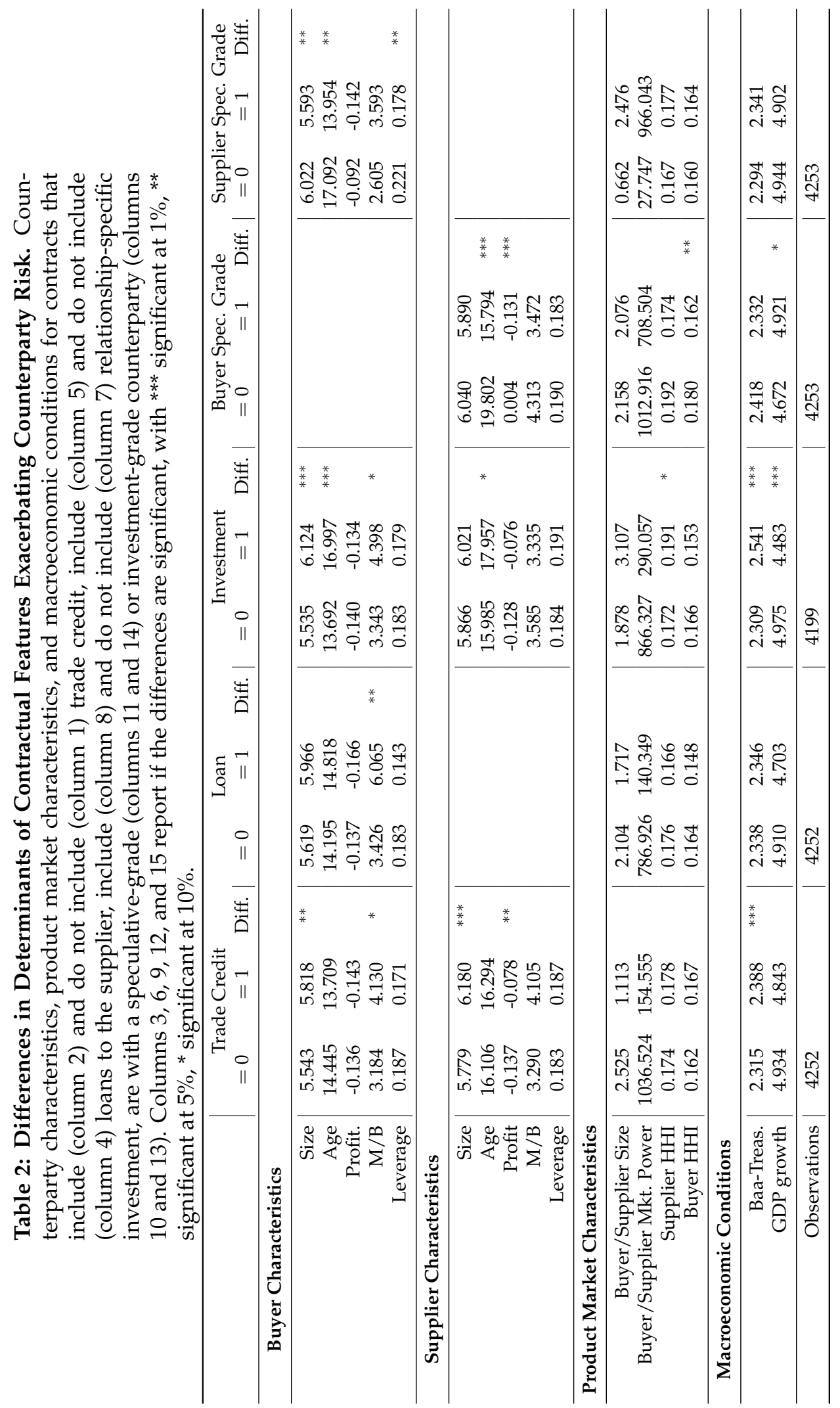


Table 3: Differences in Determinants of Contractual Features Mitigating Counterparty Risk. Counterparty characteristics, product market characteristics, and macroeconomic conditions for contracts that include (column 2) and do not include (column 1) financial covenants and for contracts that include (column 5) and do not include product warranties (column 4). Columns 3 and 6 report if the differences are significant, with ${ }^{* * *}$ significant at $1 \%,{ }^{* *}$ significant at $5 \%,{ }^{*}$ significant at $10 \%$.

\begin{tabular}{|c|c|c|c|c|c|c|}
\hline & \multicolumn{3}{|c|}{ Fin. Cov. } & \multicolumn{3}{|c|}{ Prod. Warrant } \\
\hline & $=0$ & $=1$ & Diff. & $=0$ & $=1$ & Diff. \\
\hline \multicolumn{7}{|l|}{ Buyer Characteristics } \\
\hline Size & 5.483 & 6.065 & $* * *$ & 5.834 & 5.513 & $* * *$ \\
\hline Age & 13.478 & 16.465 & $* * *$ & 16.242 & 13.072 & $* * *$ \\
\hline Profit. & -0.136 & -0.146 & & -0.091 & -0.166 & $* * *$ \\
\hline $\mathrm{M} / \mathrm{B}$ & 3.477 & 3.609 & & 3.280 & 3.630 & \\
\hline Leverage & 0.183 & 0.178 & & 0.191 & 0.177 & \\
\hline \multicolumn{7}{|l|}{ Supplier Characteristics } \\
\hline Size & 5.796 & 6.075 & * & & & \\
\hline Age & 15.986 & 16.917 & & & & \\
\hline Profit & -0.129 & -0.104 & & & & \\
\hline $\mathrm{M} / \mathrm{B}$ & 3.581 & 3.391 & & & & \\
\hline Leverage & 0.184 & 0.189 & & & & \\
\hline \multicolumn{7}{|l|}{ Product Market Characteristics } \\
\hline Buyer/Supplier Size & 1.689 & 2.912 & & 2.452 & 1.820 & \\
\hline Buyer/Supplier Mkt. Power & 437.160 & 1352.811 & & 132.259 & 1255.891 & \\
\hline Buyer HHI & 0.183 & 0.158 & $* * *$ & 0.162 & 0.185 & $* * *$ \\
\hline Supplier HHI & 0.168 & 0.152 & $* *$ & 0.156 & 0.168 & $* *$ \\
\hline \multicolumn{7}{|l|}{ Macroeconomic Conditions } \\
\hline Baa-Treas. & 2.335 & 2.353 & & 2.295 & 2.362 & ** \\
\hline GDP growth & 4.935 & 4.848 & & 5.031 & 4.838 & $* * *$ \\
\hline Observations & 4199 & & & 4219 & & \\
\hline
\end{tabular}


Table 4: Contract Announcement Date Abnormal Returns. Five day cumulative abnormal returns around contract filing dates and the date of the first press release mentioning the contract. Abnormal returns are calculated relative to the market portfolio, using $(-2,2)$ day event window. " $\times$ Fin. Covenant" is the indicator of financial covenants in the contract, " $\times$ Payment Deferred" is the indicator of payment deferred past delivery date, " $\times$ Speculative Grade" is the indicator of a speculative-grade customer (supplier) for the supplier (customer) panel; " $\times$ Product Warranty" is the indicator of product warranties in the contract; " $\times$ Investment" is the indicator of relationship-specific investment by the supplier; " $\times$ Conc. Industry" is the indicator of the customer (supplier) being in a concentrated industry. Regressions include industry (4 digit SIC code) fixed effects. Clustered (by year) standard errors shown in brackets. ${ }^{* * *}$ significant at $1 \%,{ }^{* *}$ significant at $5 \%$, ${ }^{*}$ significant at $10 \%$.

\begin{tabular}{|c|c|c|c|c|c|c|}
\hline & \multicolumn{3}{|c|}{ Contract Filing } & \multicolumn{3}{|c|}{ Press Release } \\
\hline & 1 & 2 & 3 & 4 & 5 & 6 \\
\hline \multirow[t]{2}{*}{ Abn. Ret. } & 0.015 & 1.826 & 1.171 & 0.253 & 0.933 & 1.409 \\
\hline & {$[0.302]$} & {$[1.140]$} & [0.810] & {$[0.862]$} & {$[2.948] \quad[1$} & [15.549] \\
\hline \multirow[t]{2}{*}{$\times$ Fin. Covenant } & & 0.022 & 0.140 & & -0.788 & -0.337 \\
\hline & & {$[0.511]$} & {$[0.473]$} & & {$[1.376] \quad[$} & [0.603] \\
\hline \multirow[t]{2}{*}{$\times$ Loan Extended } & & -2.267 & -2.212 & & 7.051 & \\
\hline & & {$[1.128]^{*}$} & {$[1.114]^{*}$} & & {$[4.374]$} & \\
\hline$\times$ Payment Advanced & & $\begin{array}{c}-0.882 \\
{[0.752]}\end{array}$ & $\begin{array}{l}-0.173 \\
{[0.521]}\end{array}$ & & $\begin{array}{ll}2.848 & - \\
{[2.626]} & -\end{array}$ & $\begin{array}{l}-0.869 \\
{[4.199]}\end{array}$ \\
\hline$\times$ Speculative Grade & & $\begin{array}{l}-0.767 \\
{[0.722]}\end{array}$ & $\begin{array}{l}-1.134 \\
{[0.666]}\end{array}$ & & & \\
\hline \multirow[t]{2}{*}{$\times$ Product Warranty } & & -0.639 & 0.054 & & $-4.581-$ & -6.803 \\
\hline & & [0.899] & {$[0.416]$} & & [3.468] $\quad[\varepsilon$ & [8.840] \\
\hline \multirow[t]{2}{*}{$\times$ Investment } & & -0.343 & -0.194 & & -0.950 & -4.403 \\
\hline & & [0.931] & [0.935] & & [2.627] & [4.936] \\
\hline \multirow[t]{2}{*}{$\times$ EBITDA $/$ AT } & & & 0.185 & & & -16.939 \\
\hline & & & [1.152] & & & {$[7.564]^{*}$} \\
\hline$\times$ Sales $/$ AT & & & $\begin{array}{l}-0.099 \\
{[0.811]}\end{array}$ & & & $\begin{array}{c}4.049 \\
{[14.073]}\end{array}$ \\
\hline \multirow[t]{4}{*}{ Observations } & 1173 & 1161 & 1154 & 70 & 70 & 36 \\
\hline & Pant & el $B: C$ & ustomer & & & \\
\hline & Cor & ntract Fili & ing & & ess Releas & \\
\hline & 1 & 2 & 3 & 4 & 5 & 6 \\
\hline \multirow[t]{2}{*}{ Abn. Ret. } & 0.585 & 0.530 & 0.186 & 2.110 & 4.637 & 4.104 \\
\hline & {$[0.281]^{*}$} & [1.222] & [1.524] & {$[0.621]^{* * *}$} & [4.198] & ] [7.027] \\
\hline \multirow[t]{2}{*}{$\times$ Fin. Covenant } & & 1.332 & 1.406 & & 0.077 & 0.305 \\
\hline & & {$[0.820]$} & {$[0.805]^{*}$} & & [1.435] & ] [2.342] \\
\hline \multirow[t]{2}{*}{$\times$ Loan Extended } & & -0.095 & -0.125 & & 1.033 & 4.227 \\
\hline & & [1.874] & [1.888] & & [3.427] & ] [4.381] \\
\hline \multirow[t]{2}{*}{$\times$ Payment Deferred } & & -0.567 & -0.496 & & -0.133 & 0.277 \\
\hline & & {$[0.440]$} & [0.448] & & [1.077] & ] [1.630] \\
\hline \multirow[t]{2}{*}{$\times$ Speculative Grade } & & 0.261 & 0.351 & & -1.956 & 2.883 \\
\hline & & [1.351] & [1.319] & & [4.483] & [4.015] \\
\hline \multirow[t]{2}{*}{$\times$ Product Warranty } & & -0.305 & -0.394 & & -0.922 & 0.020 \\
\hline & & {$[0.563]$} & [0.649] & & [1.357] & [2.615] \\
\hline \multirow{2}{*}{$\times$ Investment } & & -0.852 & -0.894 & & -1.694 & 0.006 \\
\hline & & [0.852] & [0.837] & & {$[1.780]$} & [3.654] \\
\hline \multirow[t]{2}{*}{$\times$ EBITDA $/$ AT } & & & -0.191 & & & -0.706 \\
\hline & & & [1.300] & & & [1.266] \\
\hline \multirow[t]{2}{*}{$\times$ Sales $/$ AT } & & & 0.386 & & & -9.473 \\
\hline & & & {$[0.683]$} & & & [9.631] \\
\hline Observations & 1351 & 1343 & 1335 & 64 & 64 & 47 \\
\hline
\end{tabular}


Table 5: Momentum Strategy, Abnormal Returns 1994-2013. Calendar-time portfolio abnormal returns. At the beginning of every calendar month, stocks are ranked in ascending order on the basis of the return of a portfolio of its publicly traded customers (suppliers) over the preceding three months. The ranked stocks are assigned to one of five quintile portfolios. All stocks are value weighted within a given portfolio, and the portfolios are rebalanced every calendar month to maintain value weights. Upstream (downstream) momentum refers to the impact of news about customers (suppliers) on the return of the supplier (customer). Alpha is the intercept on a regression of the quarterly excess returns from the rolling strategy that holds the top $20 \%$ of high customer (supplier) return stocks and sells short the bottom $20 \%$ of low customer (supplier) return stocks. The explanatory variables are the quarterly returns from Fama and French (1993) mimicking portfolios, Carhart (1997) momentum factor, the Pastor and Stambaugh (2003) traded liquidity factor, and supplier (customer) fixed effects. Returns and alphas are in quarterly units. Newey-West standard errors (3 lags) in brackets. ${ }^{* * *}$ significant at $1 \%,{ }^{* *}$ significant at $5 \%,{ }^{*}$ significant at $10 \%$.

\section{Panel A: Upstream Momentum}

\begin{tabular}{lccccc}
\hline & Excess Ret. & 3 Factor Alpha & 4 Factor Alpha & 5 Factor Alpha & 5 Factor Alpha \\
\hline High-Low Customer Return & 0.744 & 1.838 & 1.807 & 1.879 & 1.951 \\
& {$[0.985]$} & {$[0.879]^{* *}$} & {$[0.865]^{* *}$} & {$[0.878]^{* *}$} & {$[0.883]^{* *}$} \\
\hline Supp. FE & No & No & No & No & Yes \\
\hline Adj. $R^{2}$ & 0.001 & 0.186 & 0.188 & 0.188 & 0.239 \\
N. obs & 13948 & 13948 & 13948 & 13895 & 13895 \\
\hline \multicolumn{5}{c}{ Panel B: Downstream Momentum } \\
\hline High-Low Supplier Return & 0.395 & 0.206 & 0.592 & 1.190 & \\
\hline Cust. FE & {$[0.972]$} & {$[0.784]$} & {$[0.792]$} & {$[0.872]$} & {$[0.940]^{*}$} \\
\hline Adj. $R^{2}$ & No & No & No & No & Yes \\
N. obs & 0.001 & 0.224 & 0.226 & 0.226 & 0.273 \\
\hline & 14232 & 14232 & 14232 & 14173 & 14173 \\
\hline
\end{tabular}


Table 6: Momentum Strategy and Contractual Relationship, Abnormal Returns 1994-2013. Calendartime portfolio abnormal returns. At the beginning of every calendar month, stocks are ranked in ascending order on the basis of the return of a portfolio of its publicly traded customers (suppliers) over the preceding three months. The ranked stocks are assigned to one of five quintile portfolios. All stocks are value weighted within a given portfolio, and the portfolios are rebalanced every calendar month to maintain value weights. Upstream (downstream) momentum refers to the impact of news about customers (suppliers) on the return of the supplier (customer). Alpha is the intercept on a regression of the quarterly excess returns from the rolling strategy that holds the top $20 \%$ of high customer (supplier) return stocks and sells short the bottom $20 \%$ of low customer (supplier) return stocks. " $\times$ Contract" is the coefficient on the indicator variable of a contractual relationship between the customer and supplier. The explanatory variables are the quarterly returns from Fama and French (1993) mimicking portfolios, Carhart (1997) momentum factor, the Pastor and Stambaugh (2003) traded liquidity factor, and supplier (customer) fixed effects. Returns and alphas are in quarterly units. Newey-West standard errors (3 lags) in brackets. ${ }^{* * *}$ significant at $1 \%$, ${ }^{* *}$ significant at $5 \%,{ }^{*}$ significant at $10 \%$.

Panel A: Upstream Momentum

\begin{tabular}{|c|c|c|c|c|c|}
\hline & Excess Ret. & 3 Factor Alpha & 4 Factor Alpha & 5 Factor Alpha & 5 Factor Alpha \\
\hline \multirow[t]{2}{*}{ High-Low Customer Return } & -0.080 & -0.062 & -0.064 & -0.063 & -0.159 \\
\hline & {$[0.029]^{* * *}$} & {$[0.024]^{* * *}$} & {$[0.024]^{* * *}$} & {$[0.023]^{* * *}$} & {$[0.080]^{* *}$} \\
\hline \multirow[t]{2}{*}{$\times$ Contract } & 0.824 & 2.111 & 2.031 & 2.051 & 2.098 \\
\hline & [0.985] & {$[0.884]^{* *}$} & {$[0.880]^{* *}$} & {$[0.868]^{* *}$} & {$[0.842]^{* *}$} \\
\hline Supp. FE & No & No & No & No & Yes \\
\hline Adj. $R^{2}$ & 0.013 & 0.188 & 0.190 & 0.197 & 0.227 \\
\hline N. obs & 161622 & 161622 & 161622 & 161569 & 161569 \\
\hline \multicolumn{6}{|c|}{ Panel B: Downstream Momentum } \\
\hline & Excess Ret. & 3 Factor Alpha & 4 Factor Alpha & 5 Factor Alpha & 5 Factor Alpha \\
\hline \multirow[t]{2}{*}{ High-Low Supplier Return } & -0.051 & -0.254 & -0.087 & 0.157 & 0.175 \\
\hline & {$[0.015]^{* * *}$} & {$[0.111]^{* *}$} & [0.153] & {$[0.174]$} & [0.177] \\
\hline \multirow[t]{2}{*}{$\times$ Contract } & 0.493 & 0.881 & 0.847 & 0.833 & 1.037 \\
\hline & {$[0.978]$} & {$[0.786]$} & {$[0.788]$} & [0.789] & [0.789] \\
\hline Cust. FE & No & No & No & No & Yes \\
\hline Adj. $R^{2}$ & 0.061 & 0.264 & 0.264 & 0.268 & 0.292 \\
\hline N. obs & 98991 & 98991 & 98991 & 98932 & 98932 \\
\hline
\end{tabular}


Table 7: Momentum Strategy and Financial Covenants, Abnormal Returns 1994-2013. Calendar-time portfolio abnormal returns. At the beginning of every calendar month, stocks are ranked in ascending order on the basis of the return of a portfolio of its publicly traded customers (suppliers) over the preceding three months. The ranked stocks are assigned to one of five quintile portfolios. All stocks are value weighted within a given portfolio, and the portfolios are rebalanced every calendar month to maintain value weights. Upstream (downstream) momentum refers to the impact of news about customers (suppliers) on the return of the supplier (customer). Alpha is the intercept on a regression of the quarterly excess return from the rolling strategy that holds the top $20 \%$ of high customer (supplier) return stocks and sells short the bottom $20 \%$ of low customer (supplier) return stocks. " $\times$ Fin. Covenant" is the coefficient on the indicator variable of the presence of financial covenants in the supply contract. The explanatory variables are the quarterly returns from Fama and French (1993) mimicking portfolios, Carhart (1997) momentum factor, the Pastor and Stambaugh (2003) traded liquidity factor, and supplier (customer) fixed effects. Returns and alphas are in quarterly units. Newey-West standard errors (3 lags) in brackets. ${ }^{* * *}$ significant at $1 \%,{ }^{* *}$ significant at $5 \%$, * significant at $10 \%$.

Panel A: Upstream Momentum

\begin{tabular}{|c|c|c|c|c|c|}
\hline & Excess Ret. & 3 Factor Alpha & 4 Factor Alpha & 5 Factor Alpha & 5 Factor Alpha \\
\hline \multirow[t]{2}{*}{ High-Low Customer Return } & 2.934 & 3.305 & 3.068 & 2.847 & 2.588 \\
\hline & {$[1.200]^{* *}$} & {$[1.093]^{* * *}$} & {$[1.036]^{* * *}$} & {$[1.022]^{* * *}$} & {$[1.001]^{* * *}$} \\
\hline \multirow{2}{*}{$\times$ Fin. Covenant } & -5.918 & -4.542 & -4.335 & -4.360 & -3.676 \\
\hline & {$[1.672]^{* * *}$} & {$[1.515]^{* * *}$} & {$[1.484]^{* * *}$} & {$[1.478]^{* * *}$} & {$[1.453]^{* *}$} \\
\hline Supp. FE & No & No & No & No & Yes \\
\hline Adj. $R^{2}$ & 0.006 & 0.185 & 0.188 & 0.195 & 0.239 \\
\hline \multirow[t]{3}{*}{ N. obs } & 14860 & 14860 & 14860 & 14845 & 14845 \\
\hline & Panel B & 3: Downstream & Momentum & & \\
\hline & Excess Ret. & 3 Factor Alpha & 4 Factor Alpha & 5 Factor Alpha & 5 Factor Alpha \\
\hline \multirow[t]{2}{*}{ High-Low Supplier Return } & 1.394 & 2.040 & 2.400 & 2.750 & 3.113 \\
\hline & [1.150] & {$[0.993]^{* *}$} & {$[1.006]^{* *}$} & {$[1.038]^{* * *}$} & {$[1.083]^{* * *}$} \\
\hline \multirow{2}{*}{$\times$ Fin. Covenant } & -1.880 & -3.037 & -2.954 & -3.028 & -3.057 \\
\hline & [2.048] & {$[1.604]^{*}$} & {$[1.596]^{*}$} & {$[1.583]^{*}$} & {$[1.607]^{*}$} \\
\hline Cust. FE & No & No & No & No & Yes \\
\hline Adj. $R^{2}$ & 0.005 & 0.242 & 0.244 & 0.249 & 0.291 \\
\hline N. obs & 14582 & 14582 & 14582 & 14582 & 14582 \\
\hline
\end{tabular}


Table 8: Momentum Strategy and Trade Credit, Abnormal Returns 1994-2013. Calendar-time portfolio abnormal returns. At the beginning of every calendar month, stocks are ranked in ascending order on the basis of the return of a portfolio of its publicly traded customers (suppliers) over the preceding three months. The ranked stocks are assigned to one of five quintile portfolios. All stocks are value weighted within a given portfolio, and the portfolios are rebalanced every calendar month to maintain value weights. Upstream (downstream) momentum refers to the impact of news about customers (suppliers) on the return of the supplier (customer). Alpha is the intercept on a regression of the quarterly excess return from the rolling strategy that holds the top $20 \%$ of high customer (supplier) return stocks and sells short the bottom $20 \%$ of low customer (supplier) return stocks. " $\times$ Payment Deferred (Advanced)" is the coefficient on the indicator variable of contractually-specified deferment (advance) of payment by the customer to the supplier on delivery; " $\times$ Loan Extended" is the coefficient on the indicator variable of a contractuallyspecified loan from the customer to the supplier. The explanatory variables are the quarterly returns from Fama and French (1993) mimicking portfolios, Carhart (1997) momentum factor, the Pastor and Stambaugh (2003) traded liquidity factor, and supplier (customer) fixed effects. Returns and alphas are in quarterly units. Newey-West standard errors (3 lags) in brackets. ${ }^{* * *}$ significant at $1 \%,{ }^{* *}$ significant at $5 \%$, * significant at $10 \%$.

Panel A: Upstream Momentum

\begin{tabular}{|c|c|c|c|c|c|}
\hline & Excess Ret. & 3 Factor Alpha & 4 Factor Alpha & 5 Factor Alpha & 5 Factor Alpha \\
\hline High-Low Customer Return & $\begin{array}{c}0.929 \\
1625]\end{array}$ & 2.106 & 2.049 & 2.126 & $\begin{array}{c}1.659 \\
11271\end{array}$ \\
\hline$\times$ Payment Deferred & $\begin{array}{c}-0.312 \\
{[1.920]}\end{array}$ & $\begin{array}{c}-1.488 \\
{[1.559]}\end{array}$ & $\begin{array}{c}-1.512 \\
{[1.589]}\end{array}$ & $\begin{array}{l}-1.268 \\
{[1.554]}\end{array}$ & $\begin{array}{c}-0.663 \\
{[1.553]}\end{array}$ \\
\hline Supp. FE & No & No & No & No & Yes \\
\hline $\begin{array}{l}\text { Adj. } R^{2} \\
\text { N. obs }\end{array}$ & $\begin{array}{c}0.003 \\
14425\end{array}$ & $\begin{array}{l}0.182 \\
14425\end{array}$ & $\begin{array}{l}0.188 \\
14425\end{array}$ & $\begin{array}{l}0.196 \\
14391\end{array}$ & $\begin{array}{l}0.237 \\
14391\end{array}$ \\
\hline \multicolumn{6}{|c|}{ Panel B: Downstream Momentum } \\
\hline & Excess Ret. & 3 Factor Alpha & 4 Factor Alpha & 5 Factor Alpha & 5 Factor Alpha \\
\hline High-Low Supplier Return & $\begin{array}{c}-0.374 \\
{[1.270]}\end{array}$ & $\begin{array}{c}-0.046 \\
{[0.982]}\end{array}$ & $\begin{array}{c}0.012 \\
{[1.014]}\end{array}$ & $\begin{array}{c}0.490 \\
{[1.097]}\end{array}$ & $\begin{array}{c}1.072 \\
{[1.136]}\end{array}$ \\
\hline$\times$ Payment Advanced & $\begin{array}{c}1.022 \\
{[1.966]}\end{array}$ & $\begin{array}{c}1.202 \\
{[1.610]}\end{array}$ & $\begin{array}{c}1.156 \\
{[1.602]}\end{array}$ & $\begin{array}{c}1.021 \\
{[1.586]}\end{array}$ & $\begin{array}{c}0.379 \\
{[1.651]}\end{array}$ \\
\hline Cust. FE & No & No & No & No & Yes \\
\hline $\begin{array}{l}\text { Adj. } R^{2} \\
\text { N. obs }\end{array}$ & $\begin{array}{l}0.008 \\
14113\end{array}$ & $\begin{array}{l}0.245 \\
14113\end{array}$ & $\begin{array}{l}0.248 \\
14113\end{array}$ & $\begin{array}{l}0.252 \\
14113\end{array}$ & $\begin{array}{l}0.287 \\
14113\end{array}$ \\
\hline \multicolumn{6}{|c|}{ Panel C: Downstream Momentum } \\
\hline & Excess Ret. & 3 Factor Alpha & 4 Factor Alpha & 5 Factor Alpha & 5 Factor Alpha \\
\hline $\begin{array}{l}\text { High-Low Supplier Return } \\
\times \text { Loan Extended }\end{array}$ & $\begin{array}{c}0.445 \\
{[0.675]} \\
-1.977 \\
{[6.881]} \\
\end{array}$ & $\begin{array}{c}0.173 \\
{[0.566]} \\
7.629 \\
{[3.699]^{* *}} \\
\end{array}$ & $\begin{array}{c}0.294 \\
{[0.576]} \\
10.381 \\
{[3.980]^{* * *}}\end{array}$ & $\begin{array}{c}0.541 \\
{[0.606]} \\
11.391 \\
{[4.125]^{* * *}}\end{array}$ & $\begin{array}{c}0.399 \\
{[0.625]} \\
10.928 \\
{[3.743]^{* * *}}\end{array}$ \\
\hline Cust. FE & No & No & No & No & Yes \\
\hline $\begin{array}{l}\text { Adj. } R^{2} \\
\text { N. obs }\end{array}$ & $\begin{array}{l}0.000 \\
13905\end{array}$ & $\begin{array}{l}0.221 \\
13905\end{array}$ & $\begin{array}{l}0.222 \\
13905\end{array}$ & $\begin{array}{c}0.225 \\
13846\end{array}$ & $\begin{array}{c}0.265 \\
13846\end{array}$ \\
\hline
\end{tabular}


Table 9: Momentum Strategy and Credit Risk, Abnormal Returns 1994-2013. Calendar-time portfolio abnormal returns. At the beginning of every calendar month, stocks are ranked in ascending order on the basis of the return of a portfolio of its publicly traded customers (suppliers) over the preceding three months. The ranked stocks are assigned to one of five quintile portfolios. All stocks are value weighted within a given portfolio, and the portfolios are rebalanced every calendar month to maintain value weights. Upstream (downstream) momentum refers to the impact of news about customers (suppliers) on the return of the supplier (customer). Alpha is the intercept on a regression of the quarterly excess return from the rolling strategy that holds the top $20 \%$ of high customer (supplier) return stocks and sells short the bottom $20 \%$ of low customer (supplier) return stocks. For the upstream (downstream) momentum portfolio, " $\times$ Speculative Grade" is the coefficient on the indicator variable that the customer (supplier) has a speculative grade (below BBB-) rating. The explanatory variables are the quarterly returns from Fama and French (1993) mimicking portfolios, Carhart (1997) momentum factor, the Pastor and Stambaugh (2003) traded liquidity factor, and supplier (customer) fixed effects. Returns and alphas are in quarterly units. NeweyWest standard errors (3 lags) in brackets. ${ }^{* * *}$ significant at $1 \%,{ }^{* *}$ significant at $5 \%$, ${ }^{*}$ significant at $10 \%$.

Panel A: Upstream Momentum

\begin{tabular}{|c|c|c|c|c|c|}
\hline & Excess Ret. & 3 Factor Alpha & 4 Factor Alpha & 5 Factor Alpha & 5 Factor Alpha \\
\hline High-Low Customer Return & $\begin{array}{c}-1.519 \\
{[4.766]}\end{array}$ & $\begin{array}{c}3.047 \\
{[2.960]}\end{array}$ & $\begin{array}{c}4.601 \\
{[2.668]^{*}}\end{array}$ & $\begin{array}{c}4.490 \\
{[2.672]^{*}}\end{array}$ & $\begin{array}{c}2.536 \\
{[2.692]}\end{array}$ \\
\hline$\times$ Speculative Grade & $\begin{array}{c}2.631 \\
{[4.873]}\end{array}$ & $\begin{array}{l}-0.684 \\
{[3.116]}\end{array}$ & $\begin{array}{l}-2.536 \\
{[2.804]}\end{array}$ & $\begin{array}{c}-2.337 \\
{[2.792]}\end{array}$ & $\begin{array}{l}-0.516 \\
{[2.829]}\end{array}$ \\
\hline Supp. FE & No & No & No & No & Yes \\
\hline $\begin{array}{l}\text { Adj. } R^{2} \\
\text { N. obs }\end{array}$ & $\begin{array}{c}0.002 \\
12543\end{array}$ & $\begin{array}{l}0.195 \\
12543\end{array}$ & $\begin{array}{l}0.199 \\
12543\end{array}$ & $\begin{array}{c}0.206 \\
12504\end{array}$ & $\begin{array}{c}0.248 \\
12504\end{array}$ \\
\hline \multicolumn{6}{|c|}{ Panel B: Downstream Momentum } \\
\hline & Excess Ret. & 3 Factor Alpha & 4 Factor Alpha & 5 Factor Alpha & 5 Factor Alpha \\
\hline High-Low Supplier Return & $\begin{array}{c}5.298 \\
{[3.976]}\end{array}$ & $\begin{array}{c}3.593 \\
{[3.618]}\end{array}$ & $\begin{array}{c}2.431 \\
{[3.507]}\end{array}$ & $\begin{array}{c}3.833 \\
{[3.121]}\end{array}$ & $\begin{array}{c}2.949 \\
{[2.914]}\end{array}$ \\
\hline$\times$ Speculative Grade & $\begin{array}{l}-5.590 \\
{[4.123]}\end{array}$ & $\begin{array}{c}-2.988 \\
{[3.740]}\end{array}$ & $\begin{array}{c}-1.679 \\
{[3.613]}\end{array}$ & $\begin{array}{c}-2.179 \\
{[3.207]}\end{array}$ & $\begin{array}{c}-0.927 \\
{[3.074]}\end{array}$ \\
\hline Cust. FE & No & No & No & No & Yes \\
\hline Adj. $R^{2}$ & 0.004 & 0.250 & 0.251 & 0.258 & 0.295 \\
\hline N. obs & 12184 & 12184 & 12184 & 12143 & 12143 \\
\hline
\end{tabular}


Table 10: Momentum Strategy and Product Warranties, Abnormal Returns 1994-2013. Calendar-time portfolio abnormal returns. At the beginning of every calendar month, stocks are ranked in ascending order on the basis of the return of a portfolio of its publicly traded customers (suppliers) over the preceding three months. The ranked stocks are assigned to one of five quintile portfolios. All stocks are value weighted within a given portfolio, and the portfolios are rebalanced every calendar month to maintain value weights. Upstream (downstream) momentum refers to the impact of news about customers (suppliers) on the return of the supplier (customer). Alpha is the intercept on a regression of the quarterly excess return from the rolling strategy that holds the top $20 \%$ of high customer (supplier) return stocks and sells short the bottom $20 \%$ of low customer (supplier) return stocks. " $\times$ Product Warranty" is the coefficient on the indicator variable of the presence of a product warranty in the supply contract. The explanatory variables are the quarterly returns from Fama and French (1993) mimicking portfolios, Carhart (1997) momentum factor, the Pastor and Stambaugh (2003) traded liquidity factor, and supplier (customer) fixed effects. Returns and alphas are in quarterly units. Newey-West standard errors (3 lags) in brackets. ${ }^{* * *}$ significant at $1 \%$, ** significant at $5 \%{ }^{*}$ significant at $10 \%$.

Panel A: Upstream Momentum

\begin{tabular}{|c|c|c|c|c|c|}
\hline & Excess Ret. & 3 Factor Alpha & 4 Factor Alpha & 5 Factor Alpha & 5 Factor Alpha \\
\hline High-Low Customer Return & $\begin{array}{c}0.700 \\
{[1.227]}\end{array}$ & $\begin{array}{c}1.375 \\
{[1.100]}\end{array}$ & $\begin{array}{c}1.187 \\
{[1.021]}\end{array}$ & $\begin{array}{c}1.160 \\
{[1.001]}\end{array}$ & $\begin{array}{c}1.089 \\
{[0.963]}\end{array}$ \\
\hline$\times$ Product Warranty & $\begin{array}{c}0.794 \\
{[1.748]}\end{array}$ & $\begin{array}{c}1.110 \\
{[1.550]}\end{array}$ & $\begin{array}{c}1.390 \\
{[1.508]}\end{array}$ & $\begin{array}{c}1.727 \\
{[1.483]}\end{array}$ & $\begin{array}{c}1.677 \\
{[1.477]}\end{array}$ \\
\hline Supp. FE & No & No & No & No & Yes \\
\hline $\begin{array}{l}\text { Adj. } R^{2} \\
\text { N. obs }\end{array}$ & $\begin{array}{c}0.004 \\
14924\end{array}$ & $\begin{array}{l}0.178 \\
14924\end{array}$ & $\begin{array}{c}0.187 \\
14924\end{array}$ & $\begin{array}{c}0.193 \\
14894\end{array}$ & $\begin{array}{c}0.238 \\
14894\end{array}$ \\
\hline \multicolumn{6}{|c|}{ Panel B: Downstream Momentum } \\
\hline & Excess Ret. & 3 Factor Alpha & 4 Factor Alpha & 5 Factor Alpha & 5 Factor Alpha \\
\hline $\begin{array}{l}\text { High-Low Supplier Return } \\
\times \text { Product Warranty }\end{array}$ & $\begin{array}{c}2.576 \\
{[1.384]^{*}} \\
-4.339 \\
{[1.830]^{* *}}\end{array}$ & $\begin{array}{c}1.641 \\
{[1.127]} \\
-2.168 \\
{[1.478]}\end{array}$ & $\begin{array}{c}1.927 \\
{[1.121]^{*}} \\
-1.930 \\
{[1.464]}\end{array}$ & $\begin{array}{c}2.427 \\
{[1.143]^{* *}} \\
-2.299 \\
{[1.458]}\end{array}$ & $\begin{array}{c}2.789 \\
{[1.169]^{* *}} \\
-2.693 \\
{[1.487]^{*}}\end{array}$ \\
\hline Cust. FE & No & No & No & No & Yes \\
\hline $\begin{array}{l}\text { Adj. } R^{2} \\
\text { N. obs }\end{array}$ & $\begin{array}{l}0.007 \\
14889\end{array}$ & $\begin{array}{l}0.221 \\
14889\end{array}$ & $\begin{array}{c}0.222 \\
14889\end{array}$ & $\begin{array}{c}0.230 \\
14889\end{array}$ & $\begin{array}{c}0.268 \\
14889\end{array}$ \\
\hline
\end{tabular}


Table 11: Momentum Strategy and Relationship-Specific Investment, Abnormal Returns 1994-2013. Calendar-time portfolio abnormal returns. At the beginning of every calendar month, stocks are ranked in ascending order on the basis of the return of a portfolio of its publicly traded customers (suppliers) over the preceding three months. The ranked stocks are assigned to one of five quintile portfolios. All stocks are value weighted within a given portfolio, and the portfolios are rebalanced every calendar month to maintain value weights. Upstream (downstream) momentum refers to the impact of news about customers (suppliers) on the return of the supplier (customer). Alpha is the intercept on a regression of the quarterly excess return from the rolling strategy that holds the top $20 \%$ of high customer (supplier) return stocks and sells short the bottom $20 \%$ of low customer (supplier) return stocks. " $\times$ Investment" is the coefficient on the indicator variable of contractually-specified investment by the supplier (customer). The explanatory variables are the quarterly returns from Fama and French (1993) mimicking portfolios, Carhart (1997) momentum factor, the Pastor and Stambaugh (2003) traded liquidity factor, and supplier (customer) fixed effects. Returns and alphas are in quarterly units. Newey-West standard errors (3 lags) in brackets. ${ }^{* * *}$ significant at $1 \%$, ${ }^{* *}$ significant at $5 \%$, ${ }^{*}$ significant at $10 \%$.

Panel A: Upstream Momentum

\begin{tabular}{|c|c|c|c|c|c|}
\hline & Excess Ret. & 3 Factor Alpha & 4 Factor Alpha & 5 Factor Alpha & 5 Factor Alpha \\
\hline \multirow[t]{2}{*}{ High-Low Supplier Return } & -4.683 & -6.729 & -6.465 & -5.677 & -5.748 \\
\hline & {$[2.360]^{* *}$} & {$[2.714]^{* *}$} & {$[2.807]^{* *}$} & {$[2.846]^{* *}$} & {$[2.851]^{* *}$} \\
\hline \multirow{2}{*}{$\times$ Investment } & 5.487 & 7.633 & 7.449 & 7.149 & 7.202 \\
\hline & {$[2.628]^{* *}$} & {$[2.884]^{* * *}$} & {$[2.932]^{* *}$} & {$[2.953]^{* *}$} & {$[2.948]^{* *}$} \\
\hline Cust. FE & No & No & No & No & Yes \\
\hline Adj. $R^{2}$ & 0.003 & 0.201 & 0.202 & 0.218 & 0.280 \\
\hline N. obs & 5243 & 5243 & 5243 & 5213 & 5213 \\
\hline \multicolumn{6}{|c|}{ Panel B: Downstream Momentum } \\
\hline & Excess Ret. & 3 Factor Alpha & 4 Factor Alpha & 5 Factor Alpha & 5 Factor Alpha \\
\hline \multirow[t]{2}{*}{ High-Low Supplier Return } & -3.684 & -2.324 & -2.303 & -2.297 & -2.111 \\
\hline & {$[1.364]^{* * *}$} & {$[1.121]^{* *}$} & {$[1.179]^{*}$} & {$[1.215]^{*}$} & [1.318] \\
\hline \multirow[t]{2}{*}{$\times$ Investment } & 4.153 & 6.857 & 6.662 & 6.347 & 6.340 \\
\hline & [5.889] & [4.846] & [4.991] & [4.696] & [4.772] \\
\hline Cust. FE & No & No & No & No & Yes \\
\hline Adj. $R^{2}$ & 0.017 & 0.328 & 0.331 & 0.337 & 0.350 \\
\hline N. obs & 4753 & 4753 & 4753 & 4723 & 4723 \\
\hline
\end{tabular}


Table 12: Momentum Strategy and Industry Concentration, Abnormal Returns 1994-2013.Calendar-time portfolio abnormal returns. At the beginning of every calendar month, stocks are ranked in ascending order on the basis of the return of a portfolio of its publicly traded customers (suppliers) over the preceding three months. The ranked stocks are assigned to one of four quantile portfolios. All stocks are value weighted within a given portfolio, and the portfolios are rebalanced every calendar month to maintain value weights. Upstream (downstream) momentum refers to the impact of news about customers (suppliers) on the return of the supplier (customer). Alpha is the intercept on a regression of the quarterly excess return from the rolling strategy that holds the top $20 \%$ of high customer (supplier) return stocks and sells short the bottom $20 \%$ of low customer (supplier) return stocks. For the upstream (downstream) momentum portfolio, " $\times$ Conc. Industry" is the coefficient on the indicator variable of the customer (supplier) belonging to a high concentration industry. The explanatory variables are the quarterly returns from Fama and French (1993) mimicking portfolios, Carhart (1997) momentum factor, the Pastor and Stambaugh (2003) traded liquidity factor, and supplier (customer) fixed effects. Returns and alphas are in quarterly units. Newey-West standard errors (3 lags) in brackets. ${ }^{* *}$ significant at $1 \%,{ }^{* *}$ significant at $5 \%$, ${ }^{*}$ significant at $10 \%$.

\section{Panel A: Upstream Momentum}

\begin{tabular}{|c|c|c|c|c|c|}
\hline & Excess Ret. & 3 Factor Alpha & 4 Factor Alpha & 5 Factor Alpha & 5 Factor Alpha \\
\hline \multirow[t]{2}{*}{ High-Low Customer Return } & 6.138 & 5.612 & 5.518 & 5.753 & 5.823 \\
\hline & {$[1.721]^{* * *}$} & {$[1.589]^{* * *}$} & {$[1.512]^{* * *}$} & {$[1.520]^{* * *}$} & {$[1.430]^{* * *}$} \\
\hline \multirow[t]{2}{*}{$\times$ Conc. Industry } & -7.656 & -5.430 & -5.377 & -5.268 & -5.613 \\
\hline & {$[2.027]^{* * *}$} & {$[1.908]^{* * *}$} & {$[1.852]^{* * *}$} & {$[1.824]^{* * *}$} & {$[1.724]^{* * *}$} \\
\hline Supp. FE & No & No & No & No & Yes \\
\hline Adj. $R^{2}$ & 0.009 & 0.186 & 0.187 & 0.192 & 0.233 \\
\hline N. obs & 13970 & 13970 & 13970 & 13955 & 13955 \\
\hline \multicolumn{6}{|c|}{ Panel B: Downstream Momentum } \\
\hline & Excess Ret. & 3 Factor Alpha & 4 Factor Alpha & 5 Factor Alpha & 5 Factor Alpha \\
\hline \multirow[t]{2}{*}{ High-Low Supplier Return } & -0.829 & -0.486 & -0.301 & 0.202 & 0.274 \\
\hline & [1.462] & [1.222] & [1.225] & [1.277] & [1.270] \\
\hline \multirow[t]{2}{*}{$\times$ Conc. Industry } & 1.947 & 1.342 & 1.457 & 1.163 & 1.079 \\
\hline & [1.940] & [1.555] & [1.545] & [1.530] & [1.529] \\
\hline Cust. FE & No & No & No & No & Yes \\
\hline Adj. $R^{2}$ & 0.002 & 0.248 & 0.250 & 0.256 & 0.293 \\
\hline N. obs & 13812 & 13812 & 13812 & 13812 & 13812 \\
\hline
\end{tabular}


Table 13: Momentum Strategy, Non-overlapping Abnormal Returns. Calendar-time, non-overlapping samples portfolio returns. At the beginning of every calendar quarter, stocks are ranked in ascending order on the basis of the return of a portfolio of its publicly traded customers (suppliers) over the preceding quarter. The ranked stocks are assigned to one of five quintile portfolios. All stocks are value weighted within a given portfolio, and the portfolios are rebalanced every calendar month to maintain value weights. Upstream (downstream) momentum refers to the impact of news about customers (suppliers) on the return of the supplier (customer). Alpha is the intercept on a regression of the quarterly excess return from the rolling zero-cost portfolio that holds the top $20 \%$ of high customer (supplier) return stocks and sells short the bottom $20 \%$ of low customer (supplier) return stocks. The explanatory variables are the quarterly returns from Fama and French (1993) mimicking portfolios, Carhart (1997) momentum factor, the Pastor and Stambaugh (2003) traded liquidity factor, and supplier (customer) fixed effects. " $\times$ Fin. Covenant" is the indicator of financial covenants in the contract, " $\times$ Payment Deferred" is the indicator of payment deferred past delivery date, " $\times$ Speculative Grade" is the indicator of a speculative grade customer (supplier) for the upstream (downstream) panel; " $\times$ Product Warranty" is the indicator of product warranties in the contract. Alphas are in quarterly units. Newey-West standard errors (1 lag) in brackets. ${ }^{* * *}$ significant at $1 \%$, ${ }^{* *}$ significant at $5 \%,{ }^{*}$ significant at $10 \%$.

Panel A: Upstream Momentum

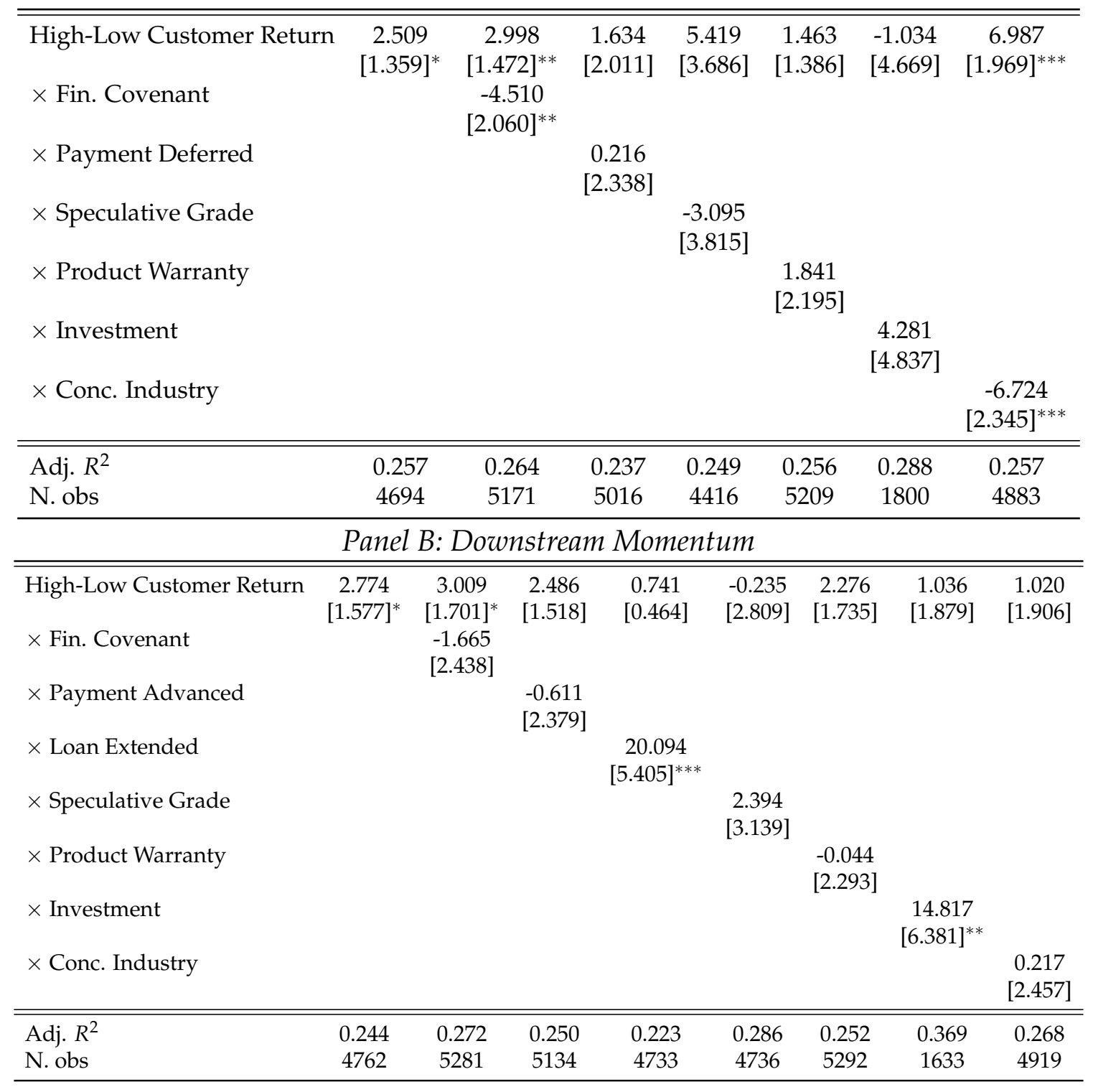


Table 14: Momentum Strategy, Pre-Contract Abnormal Returns. Calendar-time portfolio returns. At the beginning of every calendar month, stocks are ranked in ascending order on the basis of the return of a portfolio of its publicly traded customers (suppliers) over the preceding three months. The ranked stocks are assigned to one of five quintile portfolios. All stocks are value weighted within a given portfolio, and the portfolios are rebalanced every calendar month to maintain value weights. Upstream (downstream) momentum refers to the impact of news about customers (suppliers) on the return of the supplier (customer). Alpha is the intercept on a regression of the quarterly excess return from the rolling zero-cost portfolio that holds the top $20 \%$ of high customer (supplier) return stocks and sells short the bottom $20 \%$ of low customer (supplier) return stocks. The explanatory variables are the quarterly returns from Fama and French (1993) mimicking portfolios, Carhart (1997) momentum factor, the Pastor and Stambaugh (2003) traded liquidity factor, and supplier (customer) fixed effects. " $\times$ Fin. Covenant" is the indicator of financial covenants in the future contract, " $\times$ Payment Deferred" is the indicator of payment deferred past delivery date, " $\times$ Speculative Grade" is the indicator of a speculative-grade customer (supplier) for the upstream (downstream) panel; " $\times$ Product Warranty" is the indicator of product warranties in the contract. Alphas are in quarterly units. Newey-West standard errors (3 lags) in brackets. ${ }^{* * *}$ significant at $1 \%$, ${ }^{* *}$ significant at $5 \%,{ }^{*}$ significant at $10 \%$. 